\title{
KOER VÕI KUNINGAS? EESTI PEREKONNANIMEDE PÜSIVUSEST ${ }^{1}$
}

\section{FRED PUSS}

Annotatsioon. Uurimuses on genealoogilist meetodit rakendades analüüsitud 46 sugukonda (2416 nimekandjat) alates üldisest perekonnanimede panekust (1822-1835) kuni nimede massilise eestistamise alguseni (1935), esitades leviku olemasolul ka hilisemad andmed. Sugukonnad kandsid nelja negatiivse ja nelja positiivse konnotatsiooniga nime. Negatiivsed nimed pandi valdavalt talurahva alamkihtides ja väiksematele perekondadele või üksikisikutele, positiivsed ülemkihtides ja suurematele perekondadele või sugukondadele. Negatiivse nimega sugukondades on nimi hääbunud $90 \%$, positiivse nimega sugukondades $48 \%$ juhtudest. Hääbumise olulisim mõjur oli nime esmasaajate arv: suurem arv pani aluse nime laiemaks levikuks järgneval poolsajandil, uuritud ühe esmasaajaga nimedest hääbus $100 \%$. Teisena mõjutas nime levikut sugukonna hilisem demograafiline areng ning alles kolmandana negatiivse nime muutumine. Kaks esimest mõjurit olid otseselt seotud sotsiaalse staatusega: alamkihid said halvemad nimed ning nime esmasaajate ja esialgu ka järeltulijate arv oli väiksem. Nimemuutuse tõttu hääbus 33\% negatiivsetest nimedest, ülejäänud põhjused olid demograafilised. Muutused puudutasid harva ka positiivseid nimesid, kuid nende hääbumise põhjused olid alati demograafilised.

Võtmesõnad: nimeteadus, nimekorraldus, keel ja kultuur, ajalooline demograafia, sotsiaalsed kihistused

\footnotetext{
Autor tänab Allan Puuri ja Mark Gortfelderit võimaluse eest kasutada 1930. aastate perekonnaregistri andmebaasi ja 1989. aasta rahvaloenduse nimeandmeid Tallinna Ülikooli Eesti demograafia keskuse ja infotehnoloogilise mobiilsusobservatooriumi (IMO) teadustaristu kaudu. Samuti tänab autor demograafia keskuse vanemteadurit Kersti Lusti nõuannete ning rahvusarhiivi kasutusosakonna asejuhatajat Kaia Ivaskit andmete täpsustamise abi eest.
} 


\section{Sissejuhatus}

Eestis toimus üldine perekonnanimede (edaspidi ka nimi) panek aastail 1822-1835 ning hiljem mõjutas seda tugevalt nimede eestistamine peamiselt aastail 1935-1940. Kui esimene protsess oli suunatud n-ö ülevalt alla - nimed saadi sageli mõisavalitsuselt ja kirikuõpetajalt tihti ilma enda sõnaõiguseta -, siis teine protsess oli suunatud alt üles ehk nimekandjad ütlesid riigile ise, mis nime nad soovisid kanda.

Perekonnanimede muutmist kuni 1891. aastani on peetud juriidiliselt reguleerimata protsessiks ning tol aastal on vähemalt Eestimaa kubermanguvalitsus asunud seisukohale, et nimemuutmine on keisri pädevuses (Must 2000: 57). Senini oli nimesid muudetud paljuski mõisavalitsuse, kirikuõpetaja, linnaametniku jt algatusel ja äranägemisel, mõnikord ka nimekandja soovil seoses sotsiaalse staatuse tõusuga ja/või saksastumisega.

Siinses uurimuses otsitakse vastust küsimusele, kui palju mõjutas nimede muutmist alates üldisest nimepanekust kuni nimede massilise eestistamise alguseni (1935) nende negatiivne või positiivne konnotatsioon ning kas emb-kumb oli seotud ka nime loomuliku edasikandumisega. Et nimede eestistamise ajal loobuti paljudest halvakõlalistest nimedest, sh varem neutraalsena mõjunud loomanimetustest, on üldteada (Must 2000: 64) ning see oli ka tolle protsessi üks eesmärke.

Ajalooliselt patrilineaarse ühiskonnakorraldusega Eestis on perekonnanimed edasi kandunud isalt pojale, kuigi vallaslaste korral kandus nimi edasi naisliinis. Käesolevas töös antakse ülevaade konkreetsete sugukondade $^{2}$ näitel ka sellest, kui kaua püsis meesliin ning kas meesliini püsimine tagas alati perekonnanimede säilimise.

Perekonnanimede püsivuse küsimus, seda eelkõige kõrgkihtide puhul, pakkus huvi juba 19. sajandi teadlastele. Statistik Irenée Jules Bienaymé otsis vastust küsimusele, et kui rahvastik kasvab geomeetrilises progressioonis, siis kuidas suur osa perekondi ikkagi välja sureb. Ta leidis aastal 1845, et kui poegade keskmine arv põlvkonnas on üks, näiteks ühel pojal pole poegi, kuid teisel on neid kaks, on 35 põlvkonna pärast ikkagi vaid $5 \%$ (mitte aga 50\%) tõenäosus meesliinis järeltulija olemasoluks. Tema

2 Sugukond hõlmab genealoogias eelkõige ühe meesisiku kõiki meesliinis järglasi. Siin on sugukonda arvatud ka naisliinid, kui nende kaudu perekonnanimi edasi kandus. 
kirjatöö unustati enam kui sajandiks. 1875. aastal avaldas statistik ja eugeenik Francis Galton koos matemaatik Henry William Watsoniga oma teedrajava artikli ,On the probability of extinction of families“", millest sai nime Galton-Watsoni hargnev protsess, kuigi nad järeldasid ekslikult, et pikas perspektiivis on iga perekonna (meesliinis) väljasuremise tõenäosus 100\%. Paranduse tegi alles Taani matemaatik Johan Frederik Steffensen aastal 1930 ning seda täiendas ja kasutas USA 1920. aasta rahvaloenduse materjalide peal sealne rahvastikustatistik Alfred James Lotka aastal 1939. (Bacaër 2011: 41-43, 50-54, 57-58, 102-103)

Perekonnanimede püsivust on uuritud peamiselt eri aegade elanike loetelusid kõrvutades. Yasuda jt (1974: 137) on Itaalia Parma piirkonna puhul leidnud, et 17. sajandil eksisteerinud 105 nimest oli kümne põlvkonna pärast ehk 20. sajandi teiseks pooleks kadunud 61 (58\%).

Siinses töös on perekonnanimede püsimist uuritud genealoogilisel meetodil, mida Eestis on oma töömahukuse tõttu kasutatud harva ning teaduskasutuses puuduvad ka suuremad genealoogilised andmekogud. Väiksemas mahus on meetodit kasutatud näiteks perepärimuse (Jaago, Jaago 1996) ja sotsiaalsete suhete uurimisel (Johansen 1998; Peil 1999: 119-126; Tulva, Murs 2004), kuid kvantitatiivseks analüüsiks vaid piirkondlikus ajaloolises demograafias (Heldur Palli tööd 1970.-1980. aastaist; Klesment, Lust 2021 jm). Suuremahulised mittepiirkondlikud rakendused (geneetikas, meditsiinis) seisavad loodetavasti veel ees, sest andmete puudusel on seal seni kasutatud asendusmeetodeid (nt Pankratov jt 2020: 1587).

Genealoogilise meetodi vähene rakendamine on viinud isikunimede uurimisel aeg-ajalt valedele jälgedele. Suurbritannias tõi meetodi nimeteadusesse ajaloolane George Redmonds, kes oma 1970. aastal valminud doktoritöös selgitas, kuidas varem pelgalt lingvistilist analüüsi kasutades on briti onomastikud teinud nimeleksikonide koostamisel ekslikke või puudulikke järeldusi ning kuidas lisaks nime algkodudele ja muutuste kronoloogilisele jälgimisele võimaldab genealoogiline meetod selgitada välja, kas tegu oli ikka perekonnanime või hoopis lisanimega ning kas sama nime varasema ja hilisema esinemise vahel on genealoogiline või vaid lingvistiline seos (Redmonds jt 2011: 5-6, 17-18). Tema multidistsiplinaarset lähenemist on rakendatud ka hilisemates briti nimeleksikonides (Hanks jt 2016: xi).

Peale perekonnanimede püsimise uurimise on praegusel tööl ka allikaõpetuslik eesmärk nii onomastika andmebaasi (Must-Puss) 
kui ka arhiiviallikate kasutamise ja tõlgendamise seisukohalt. Samuti näitab see genealoogilise meetodi võimalusi antroponomastika uurimisel.

\section{Andmestik ja metoodika}

Analüüsiks valiti neli negatiivse (Koer, Laisk, Limukas, Paks) ja neli positiivse (Ilus, Kuningas, Tarkus, Truumees) konnotatsiooniga perekonnanime. Valikukriteerium oli nime algne saamine kolmes kuni viies kohas. Sellest on vaid üks erand: töö käigus selgus, et nimi Truumees saadi mitte viies, vaid kuues kohas, kuna Koigi ja Kingli mõisa andmed olid töö alguses Musta-Pussi andmebaasis (Must-Puss) koos, kuid tegelikult oli tegu kahe eraldi mõisaga ja Koigi nimed (sh Truumees) olid puudu. Negatiivse ja positiivse konnotatsiooni määramisel on lähtutud nimega kattuvast apellatiivist. Konkreetse nime algne tähendussisu võis olla neutraalne, näiteks Koer < Gregorius (EKNR 2016: Koeri), kuid pole kahtlust, et juba nime tekke ajal eksisteerinud apellatiivne vaste mõjutas hinnangut nimele. Nime algse etümoloogia välja selgitamine polnud töö eesmärk, varasema onomastilise traditsiooni olemasolu saab täheldada vaid üksikutel juhtudel, kus lähtekohaks on lisanimi (talunimi). Nimede valik on subjektiivne, lähtudes eelkõige optimaalsest uurimistöö mahust. Näiteks paljusid positiivse konnotatsiooniga nimesid pandi siinse töö jaoks liiga paljudel kordadel (nt Tark 13 korral, Truu 33), enamikku eriti negatiivse konnotatsiooniga nimesid aga liiga vähestel kordadel (nt Porikoll 1, Durakmees 1, Katk 1, Loll 2).

Siinkirjutaja on onomastika andmebaasi (Must-Puss) täiendades leidnud, et üsna sageli on sealt puudu ainult naisterahvastele pandud nimesid Liivimaalt. Põhjus on andmebaasi esialgse koostamise meetod: sisestati hingeloendite ees olevad registrid. Seal kajastuvad väheste eranditega vaid meestele pandud perekonnanimed. Näiteks Võnnu kihelkonna nelja mõisa puhul oli puudu 0-11\% nimedest (Puss 2020: 70). Vana-Kuuste mõisas on registris (ja perekonnanimede numbritega) 178 nime, sisus leidub aga veel 38 nime (koguhulgast seega 18\%), mis pandi enamasti üksikutele naisterahvastele (EAA.1865.2.7/8). Seetõttu on Musta-Pussi andmebaasist puudu ligikaudu 1500-2000 nime ning nende hulgas võib olla ka mõni siin vaadeldud nimi. Kuna andmebaasist puuduvad nimed pandi valdavalt (üksikutele) naisterahvastele, siis nende järgmisse põlvkonda edasi 
kandumise tõenäosus oli väike, samas kui piirkonnas pandud nimede loetelu analüüsimiseks on nad olulised.

Haruldasematel nimedel selgitati välja kõikvõimalikud nime esinemise juhud enne 1935. aastat ning koondati andmed sugukonniti. Mõnel puhul selgus vastava nime teke ka pärast üldist nimepanekut (enamasti üksikinimesel nimemuutuse tõttu). Sellised juhud on esitatud eraldi sugukondadena. Levinuimate nimede puhul (Kuningas, Ilus) ei saa välistada, et neil leidus lisaks siintooduile veel esinemisjuhte.

Genealoogiline meetod eeldab põlvnemisandmete kogumist vaadeldava inimrühma kohta. Meetodiga selgiti välja esimeste nimesaajate ning nende nimekandjatest järeltulijate andmed kuni surmani või nimevahetuseni abiellumise või nime muutmise tõttu. Alati ei ole teada, kas ühes mõisas või mõisakobaras (edaspidi ka mõisas) pandud nime on saanud veresugulased või vähemalt ühe pere liikmed (näiteks koos mehega ka tema naiseõde). Suguluse välja selgitamine ei olnud töö eesmärk, kuid ühest mõisast pärit ühe nime kandjaid on käsitletud ühe sugukonnana, mida nad nimepaneku eeskirjade järgi pididki olema, kuid praktikas alati ei olnud. Kokku analüüsiti 46 sugukonda 2416 nimekandjaga kuni 1935. aastani, hilisemast ajast on esitatud hinnangulisi andmeid nimekandjate praeguse arvu kohta või selgitatud välja nime hääbumise aasta. Sugukondade nimekandjate arv on 1-616. Enam kui saja nimekandjaga sugukondi on kuus, alla kümne kandjaga 19, ühe kandjaga kuus $(1,3,6,9,12,21)$, neist kaks $(3,6)$ ei tekkinud üldisel nimepanekul.

Kümnel puhul oli tegu nime hilisema tekkega rööpnime või ka eksimuse tõttu. Neist kuuel $(3,6,18,22,32,37)$ oli nimekandjate koguarv 1-4 ehk üksikisik või abielupaar mõne lapsega ja nimi eksisteeriski vaid ühe-kahe põlvkonna jooksul. Selliste hulka pole loetud 1921.-1922. aastal Petserimaal ja Narvatagusel saadud nimed, mis tekkisid esmakordse perekonnanimena, mitte varieerumisest teise perekonnanimega.

Raskusi andmete kogumisel tekitas kõige enam õigeusku minek alates XIX sajandi keskpaigast ning Venemaale väljaränne enamasti alates 1870. aastaist (harva ka varem). Rahvastiku arvestuse allikad õigeusklike kohta on luterlaste omadest andmevaesemad ning puuduvad järjepidevad koguduseliikmete nimekirjad. Seetõttu on õigeusklikke hõlmanud sugukondade puhul esitatud statistika lapseeas surnute kohta tõenäoliselt alaregistreeritud (nad võisid nn arvestusaastal elus olla). Kuna alates 1920. aastaist ei registreerinud paljud inimesed oma perekonnaseisusündmusi 
ka enam luteri kogudustes, võib olla alaregistreerimist selleski perioodis, samuti ei saa välistada üleregistreerimist. Näiteks võis keegi olla piirkonnast lahkunud ja luteri kirikuraamatutes ei kajastunud tema surm või ka võimalik abielu ja lapsed ning ta on arvestatud 1935. a üksiku elusoleva nimekandjana. Samas on kasutatud kõikvõimalikke kättesaadavaid andmestikke (elanike nimekirjad, kalmistute andmebaasid, Eestist II maailmasõja ajal lahkunute andmebaas, rahvusarhiivi infosüsteem AIS, genealoogiaalane ühisloomeplatvorm Geni, 1959. a rahvaloenduse andmebaas Saaremaa kohta, digiteeritud trükiste kogud Digar, DEA, ETERA, Eesti Isikulooline Indeks, FamilySearch, Ancestry jne). Kõikide nimede puhul peale Ilusa ja Kuninga kasutati ka 1926-1949 peetud perekonnaregistrite andmebaasi lisaandmetega indeksit Eesti demograafia keskuses. Seega on tollal elanud täisealiste kohta andmestik enam-vähem täielik, nimede Ilus ja Kuningas andmed 1935. aastast on aga tõenäoliselt mõnevõrra alahinnatud.

Venemaale läinute kohta on kontrollitud Eestisse opteerida soovinute, stalinlike repressioonide ja II maailmasõjas langenute andmestikke, kuid need andmed ei kajasta kunagi kõiki perekonnaliikmeid. Näiteks mehe represseerimise andmete leidumisel ei ole teada, kas ta oli abielus ja lastega. Seetõttu pole välistatud, et mõne hääbunuks peetud perekonnanime kandja on elanud Venemaal (või sealt emigreerununa mujal) või teeb seda praegugi. Läände emigreerunute puhul on valdavalt tegu II maailmasõja ajal lahkunutega. Neid andmeid on otsitud andmebaasidest kas nime hääbumise $^{3}$ või praeguse ligikaudse leviku teada saamiseks. Ühelgi puhul ei leitud, et Eestis hääbunud nimi kestab edasi väljaspool Eestit, kuigi seda esineb nimede puhul kogu maailmas (Redmonds 2016: 285).

Kuni XX sajandini oli abielulahutus harv, 1920.-1930. aastate lahutuste andmeid pole eraldi otsitud, kuigi on võimalik, et mõni lahutatud

3 Hääbumise demograafiliseks põhjuseks (D) on loetud juhtumid, kus nimekandjaid järeltulijaid ei olnud. Selle põhjused võisid olla naiste nimevahetus abiellumisega (seda on käsitletud kui mittevalikulist nimemuutust, mida ei mõjutanud nime konnotatsioon) või meeste puhul sama perekonnanimega laste puudumine. Kõik meeste nimevahetused (sh abiellumisel naise nime võtmine, mida küll ette ei tulnud) ning naiste valikuline (mitte abiellumisest tulenev) nimevahetus on liigitatud onomastiliste hääbumispõhjuste $(\mathrm{O})$ hulka. Kuna võimalusel on vaadeldud nime edasi kandumist ka väljaspool Eestit, pole Eestist lahkumist tingimata peetud nime hääbumiseks, kuigi edasiste andmete puudumisel on selline hääbumine loetud demograafiliste põhjuste hulka. Demograafilist hääbumist on vaadeldud ka pärast 1935. aastat, enamasti tänapäevani välja. 
endine abielunaine ei kandnud 1935. aastal enam uuritavat nime või just vastupidi - kandis seda. Naiste andmete vaatlemine lõpetati nende abiellumisega, kuigi näiteks Hilda Johanna Kuningas abiellus 1929, lahutas samal aastal, taastas oma neiupõlvenime, kuid abiellus uuesti 1937. Tema õde Ida Rosalie Kuningas abiellus 1929, lahutas 1930, taastas oma neiupõlvenime ning oli sellega veel 1936. Seega mõlemad 1929 abiellunud naised olid 1935 taas oma (vaatlusaluse) neiupõlvenimega. Selliste juhtude arv on minimaalne (mõnel juhul on see ka teada) ning teadaolevalt ei puuduta vähe levinud vaatlusaluseid nimesid.

Meeste puhul on eeldatud, et nad olid lasteta, kui nad polnud ametlikult abielus. Üldjuhul polnud meeste abieluvälised lapsed nende perekonnanimega, v.a juhtudel, kui laps legitimeeriti pärast vanemate abiellumist ning polnud enam abieluvälise lapse staatuses. Vabaabielust sündinud lapsed olid uuritaval perioodil ema perekonnanimega. Lapsendamisi tuli ette vaid üksikjuhtumitel ning seal on lähtutud perekonnanimest - kui see jäi perest välja lapsendatul püsima (nagu tsaariajal enamasti), siis jälgiti andmeid edasi.

Andmed on ajalooliste maakondade (lisaks Petserimaa) tähestikulises järjekorras ${ }^{4}$. Kui nimi tekkis hiljem, on kohana esitatud nime tekkekoht, mitte inimese päritolu koht. Toodud on nimekandjate arv aastail 1826 Liivimaal või 1835 Eestimaal, 1870, 1900 ja 1935 (M = mehi, $N=$ naisi) ning nime hääbumise aasta ( $\dagger$, võib olla ligikaudne $-\mathrm{u}[\mathrm{mbes}]-$ või tingimuslik $>$ [pärast aastat]). Nimekandjate hulka on arvatud ka abielunaised. Kui 1826. aasta andmed on nurksulgudes, pole vastav hingeloend säilinud ning andmed on taastatud 1834. aasta loendi ning kirikuraamatute põhjal. Algsete nimesaajate arvu järel on sotsiaalne staatus $(\mathrm{P}=$ pererahvas, $\mathrm{H}=$ koolmeistrid, $\mathrm{S}=$ sulasrahvas, $\mathrm{V}=$ vabadikud, $\mathrm{K}=$ käsitöölised). Ühe sugukonna puhul võis esineda mitu staatust, samuti võis see olla juba mõne aasta pärast erinev (nt sulasest peremeheks või vastupidi). Staatus on esitatud vaid nimede positiivse või negatiivse konnotatsiooniga seostamiseks nimepaneku hetkel.

Arvestusaastate $(1870,1900,1935)$ puhul on loetud inimesi, kes tollal kehtinud kalendri 1. jaanuaril olid selle nime kandjad. Näiteks 1870-1900 elanud inimene, samuti 1870 nimekandjaga abiellunud ja 1900 surnud

4 HA = Harjumaa (4 sugukonda), J $\ddot{A}=$ Järvamaa (2), PE = Petserimaa (3), P $\ddot{A}=$ Pärnumaa (3), SA = Saaremaa (8), TA = Tartumaa (9), VI = Virumaa (5), VL=Viljandimaa (7), VÕ = Võrumaa (5). 
naine läksid kirja vaid 1900. aasta arvestusse, sest 01.01.1870 polnud nad veel sündinud või selle nimega. Vahemike puhul on arvestatud tõenäosust. Näiteks kui tütar abiellus vahemikus 1866-1871, siis pole teda 1870 . aasta nimekandjate hulka arvestatud, kuna tõenäolisem on abiellumine aastail 1866-1869, kui 1870-1871. Kui nimekandjate arv on tõenäoliselt alaregistreeritud, on nimetatud selle põhjus (enamasti õigeusku minek ja väljaränne).

Rööpnimede puhul on levikuandmed esitatud sulgudes, kuna käibel olid mõlemad nimed (sageli isegi samas dokumendis) ning üleminekuperioodi pole iga inimese puhul võimalik tuvastada. Samuti on rööpnimede puhul nime hääbumise aasta antud ligikaudsena, tähistades selle tildega (nt $\uparrow \sim 1890$ ). Tildega on tähistatud ka rööpnimede puhul esinemissagedus, kuna alati ei selgu allikatest, milline nimemuutus või varieerumine milliste pereliikmete kohta käis. Aastani 1935 teada olevate nimekandjate koguarv on tähistatud sümboliga $\sum$.

\subsection{Koer}

Algsel kujul Koer saadi nimi ühes Eestimaa ja kolmes Liivimaa mõisas. Lisaks said Rõu Saaluse mõisas kaks venda nimeks Koira ja Krans ning Vai Arumäe mõisas Koira. Krans $\sim$ Krants $\sim$ Krantz saadi nimeks veel neljas mõisas. Siinkohal on analüüsitud vaid nimekuju Koer. Nimi võis olla esialgu ka neutraalse varjundiga (< Gregorius), kuid valdavalt on aluseks apellatiiv koer, ilma varasema onomastilise traditsioonita. Näiteks Raikkülas saadi lisaks Kass ja Kirp, Vändras Kassi ja Unt. Algse nimepaneku ajal said nime ainult sulased ja vabadikud. Kolmel korral oli tegu nime hilisema tekkega $(3,6,7)$, neist kahel korral $(3,6)$ vaid ühel inimesel, mida võib lugeda eksituseks. Kolmel puhul $(4,5,7)$ tekkis nime varieerumine, mis viiski nime Koer hääbumiseni. Kõikide varieerumiste puhul on tegu hilisema ning väga tõenäoliselt tahtliku nimemuutusega (nt Koer $>$ Kõer), mitte ebaühtlasest kirjaviisist sõltuva kirjapildiga. Demograafilistel põhjustel hääbus nimi kolmel korral $(1,2,3)$. Nimi hääbus igal pool aastaks 1907. Ühel puhul (5) on jälgitav ka välja vahetatud nime hääbumine aastal 2004. Kokku on aastani 1935 tuvastatud 82 nimekandjat.

1. HA Rapla Raikküla. 1835: 1M (S), $\sum=1, \dagger 1853$. Vallaslaps Karl (u 1820-1853) oli ainus nimekandja. 
2. PÄ Vändra Vändra. 1826: $1 \mathrm{M} 1 \mathrm{~N}=2(\mathrm{SV}), \underline{1870}: 2 \mathrm{M} 3 \mathrm{~N}=5, \sum=14$, $\dagger$ u 1900.

Hingeloendi järgi sai nime vaid kasvandik Karl (u 1799-1844), kirikuraamatute järgi ka tüdruk Ann (u 1810-1871). Karlil teadaolevalt lapselapselapsi perekonnanimega Koer ei olnud. Osa pereliikmete õigeusku mineku tõttu võivad 1870. aasta andmed olla alaregistreeritud. Nime varieerumist ei leitud.

3. SA Karja Roobaka. Esines 1882-1907, 1900: 1N, $\sum=1, \dagger 1907$.

Roobakal saadud nimi Koel $\sim$ Kool esineb kujul Koer vaid Valjala kirikuraamatutes Liina (1882-1948) puhul, kes 1907 abiellus. Karja kirikuraamatutes on tema perekonnanimi Kool.

4. TA Sangaste Keeni. 1826: $2 \mathrm{M} 3 \mathrm{~N}=5(\mathrm{~S}),(\underline{1870}: 3 \mathrm{M} 1 \mathrm{~N}=4), \sum=\sim 16$, $\uparrow \sim 1880$.

Nime sai sulaspere, edasi kandus ühe poja kaudu. Kirikuraamatutes on nimi juba 1842 Lomp, hingeloendites püsis Koer, kuid vallaliikmete nimekirjades 1875 Koer (Lomp), 1879 Lomp, siiski Venemaale ümber kirjutades $1882 \mathrm{Kepъ}$. Venemaale läinute kohta edasised andmed puuduvad, seega nimi ei pruukinud siis veel välja surra.

5. TA Äksi Sootaga. [1826: 3M4N (S)], $\sum=\sim 21, \uparrow \sim 1836 / 1858$.

Nimesaamise ajal sulasrahvas, osast sai peagi pererahvas. Hingeloendites esineb Koer, pärast ümberkirjutamist Raadile 1850 Koir (ka 1858). Kirikuraamatutes 1830 Koer, 1835 Joor, parandatud > Kõr, 1836 Koer (viimane teadaolev kord), 1857 Köer, ühel perekonnal 1850 (Koer) Kruse, 1857 Köer (Kruse). Seega, enamikul muutus Koer > Kõer, osal Koer Kõer $>$ Kruse. Nime Kõer kandjaid 1870: 3M3N =6. Nimi Kõer hääbus 2004.

6. VL Helme Leebiku. Esines $1841, \sum=1, \uparrow 1841$.

Koer esineb vaid tüdruk Reedal 1841-1851 personaalraamatus. Meetrikates on tõenäoliselt tema perekonnanimi Letta, hingeloendites Waldmann.

7. VL Viljandi Vana-Tänassilma. Esines $1829-1867, \sum=\sim 28, \dagger 1867$. Koer esineb poolemaamehe Treieri Juhani (u 1789-1838) perel personaalraamatutes $(1829,1836)$ ning meetrikates $(1836,1844,1845)$, samal ajal esineb neil meetrikates 1838 Reiel, enamasti aga Kork $\sim$ Korch $\sim$ Korg, personaalraamatutes alates 1842 Kork $\sim$ Korch $\sim$ Korg. Hingeloendites on Korch. Peremees Treieri Jaani (u 1773-1833) perel esineb perekonnanimi Koer hingeloendites vaid 1850 ühe lese ja tema tütre puhul (surnud mees/isa samas loendis on nimega Korch). Personaalraamatutes on nende perekonnanimi 1829 Leppik, 1836, 1842, 1852 Koer. Osal pereliikmetel muutus hiljemalt 1882. aastaks Koer $>$ Koor ja teistel 1875. 
aastaks Koer $>$ Kurch (Koor) pärast vahepeal teises koguduses olemist. Viimane täpselt dateeritav esinemine 1867 Koer. Tugeva variatsiooni tõttu on statistikana esitatud vaid nende arv, kes mingil hetkel mingis allikas nime Koer kandsid.

\subsection{Laisk (1989: 21, 2021: 24)}

Nimi pandi kolmes Liivimaa ja kahes Eestimaa mõisas enamasti sulastele ja vabadikele, kuid ka pererahvale (8). Ühel puhul (11, pererahvas) on tegu nime väga varajase muutumisega pärast nimepanekut ning seda võib lugeda veaparanduseks talunime alusel, kuigi Musta-Pussi andmebaasis see algse nimepanekuna ei kajastu. Analüüsitud pole Rak Kaarli nime, mis onomastika andmebaasis on varem esinenud, sest kontrollimisel osutus see nimeks Lesk. Samuti pole analüüsitud Hls Uue-Kariste nime Laesk, mis onomastika andmebaasis on normaliseeritud kujule Laisk. Nimi esines Uue-Kariste mõisa läti keelealale jääval alal (hilisem Ipiku, It Ipiḳi mõis Ruhja kirikukihelkonnas) ning ei ole teada, et see esines kunagi kujul Laisk. Nime etümoloogia võib siiski olla sama (lt laisks 'laisk, pikaldane'). Kahel puhul $(8,13)$ tekkis rööpnimi, mis ühel puhul (13) tõrjus nime Laisk välja, teisel mitte. Erandlik näide on Kapi mõisa sugukond (10), kus esiteks said nime kaks õde vallaslastega ja teiseks kõik nimekandjad peale ühe vahetasid kokkulepitult 1922. aastal oma nime. Ka suurimas sugukonnas (11) muutsid nimede eestistamise ajal pooled oma nime. Nimemuutjate põhjenduseks oli nime halb kõla või labane tähendus (ERA.76.4.1552:128, 136, 140). Kõik praegused nimekandjad on seotud selle sugukonnaga. Demograafilisel põhjusel hääbus nimi kahel, onomastilisel põhjusel kahel puhul, ühel puhul (8) oli sugukonna eri harudel eri põhjused. Kokku on aastani 1935 tuvastatud 279 nimekandjat, neist 185 ühest sugukonnast (11).

8. JÄ Anna Purdi. 1835: 6M4N = 10 (PS), 1870: 4M5N = 9, 1900: 4N, 1935: $1 \mathrm{~N}, \sum=25, \dagger 1954$.

Ühele sulase ja teisele kõrtsmiku perele (sugulus teadmata) pandud nimi. Sulaspere nimi hääbus peamiselt tütarde ja väheste järeltulijate tõttu. Viimane nimekandja vallaline Anna Laisk (1874-1954) elas Paides.

${ }^{5}$ Esitatud on 1989. aasta rahvaloenduse andmed Tallinna Ülikooli Eesti demograafia keskuses ning rahvastikuregistri andmed (https://www.eesti.ee/portaal/rrteenus. nimede_stat) seisuga 25.01.2021. Kui andmeid pole esitatud, nime ei esinenud. 
Kõrtsmiku perele ilmus peagi rööpnimi (1850 Laisk (Leist)), mis juba 1858 ainustus nii hingeloendites kui ka kirikuraamatutes.

9. SA Kärla Paadla. 1826: $1 \mathrm{M}(\mathrm{S}), \sum=1, \dagger 1836$.

Nime sai vallaline sulane Reedik (u 1772 - u 1836).

10. SA $M u h u$ Kapi. 1826: 1M3N = 4 (V), 1870: 4M6N = 10, 1900: 8M9N $=17,1935: 1 \mathrm{~N}, \sum=55, \dagger 1941$.

Nime said kaks vabadikust õde, ühel vallastütar, teisel -poeg. Vallastütrel oli omakorda vallastütar, seega nimi kandus kolm põlve edasi naisliinis, seejärel hääbus. Vallaspoja järeltulijad (27 inimest) muutsid ühtede esimestena oma nime kõik koos 1922, uus nimi Laaneväli. Nimega Laisk jäi vaid osa nimemuutjate ema, lesk Jekaterina Laisk (1847-1941).

11. TA Äksi Maramaa. [1826: $5 \mathrm{M} 1 \mathrm{~N}=6(\mathrm{P})], \underline{1870}: 19 \mathrm{M} 12 \mathrm{~N}=31, \underline{1900}$ : $30 \mathrm{M} 22 \mathrm{~N}=52,1935: 36 \mathrm{M} 36 \mathrm{~N}=72, \sum=185$.

Nime sai peremees Laisa Mihkli (u 1778-1836) perekond talunime järgi (1688 Laiska Jürgen). Hingeloendites 1834-1858 Lais (1826 pole säilinud, vaid ühel väljarännanud perel muutus: 1858 Laisk), kirikuraamatutes 1830-1839 Laas $\sim$ Las $\sim$ Lais, alates 1841 Laisk. Tõenäoliselt viidi nimi kirikuraamatutes vastavusse talunimega, kuigi esialgu oli seda püütud vältida. Hingeloendites muudeti nimesid harva ning seal jäi see esialgsele kujule. 1935-1940 muutsid 16M18N = 34 oma nime (uus nimi Kalm, Laanemets, Laes, Laido, Laik, Laisaar, Laissar, Lehtsalu, Purre, Tamme), jäi 38 nimekandjat. Praegused 24 nimekandjat on seotud selle sugukonnaga.

12. VI Kadrina Kolu. 1835: $1 \mathrm{~N}$ (S), $\sum=1, \uparrow>1834$.

Nime sai tüdruk Mari (u 1799-1835-?). Saatus teadmata, kuid hiljem seda nime seal kandis ei esine.

13. VL Paistu Holstre. 1826: 1M4N = 5 (SV), (1870: $2 \mathrm{M} 3 \mathrm{~N}=5), \sum=12$, $\dagger \sim 1890$.

Nime said kaks tüdrukutest õde, ema koos sulasest pojaga ja üks tüdruk (sugulus pole teada). Sulasest sai peremees, tekkis rööpnimi hingeloendites (1858 Laisk, genannt Sturm) ja kirikuraamatutes (1875 Tormson (Laisk)). Alates 1890 kasutati vaid nime Tormson (ka Torm). Üksiku tüdruku nimeks parandati tema venna järgi Juhkamson, seega tema puhul oli varem tegu eksimusega. 


\subsection{Limukas}

Nimi võib etümoloogiliselt olla ka neutraalne: 'lillakas (taim)', mis on vanas kirjaviisis olnud mh limmokas (Hupel 1818: 123) ja ka uues kirjaviisis limmukas limukas (Wiedemann 1973 [1893]: 501, 511), kuid kirjakeeles on valdavaks muutunud tähendus 'vihmauss' (Hupel 1818: 123; Wiedemann 1973 [1893]: 501, 511), XX sajandi algul ka 'põldtigu, seatigu' (Limax), veel hiljem üldiselt 'nälkjas'. Seetõttu võib nime konnotatsiooni lugeda vähemalt osaliselt negatiivseks, ajapikku see tugevnes.

Nimi pandi ühes Eestimaa ja kahes Liivimaa mõisas vabadikule ja sulastele. Ühes kohas hääbus teises põlvkonnas, kahes kohas XX sajandi 2. poolel. Nime olulist varieerumist ega muutmist peale ühe eestistamise ei esine. Levinuim kirjapilt oli Limokas, kuju Limukas ei esinenud kirikuraamatutes ega perekonnaseisudokumentides, küll aga Limmukas (1889, 1950). Hääbumise põhjused olid demograafilised. Kokku on aastani 1935 tuvastatud 59 nimekandjat.

14. HA Kose Oru. 1835: $1 \mathrm{M}(\mathrm{V}), \underline{1870}$ : $1 \mathrm{~N}, \sum=4, \dagger 1871$.

Vabadik Aadamal (1810-1861) oli vaid üks tütar, kes abiellus 1871. Sellega nimi hääbus.

15. TA Kursi Saduküla. 1826: $2 \mathrm{M} 1 \mathrm{~N}=3(\mathrm{~S}), \underline{1870}: 4 \mathrm{M} 4 \mathrm{~N}=8, \underline{1900}: 4 \mathrm{M} 2 \mathrm{~N}$ $=6,1935: 3 \mathrm{M}, \sum=21, \dagger 1950$.

Nime sai sulane naise ja pojaga. Hääbus pärast II maailmasõda väheste laste, mitme nekrutiks võtmise ja vallaliste meeste tõttu.

16. VL Põltsamaa Vana-Põltsamaa. [1826: 1M(S)], 1870: 4M3N =7, 1900: $5 \mathrm{M} 8 \mathrm{~N}=13, \underline{1935}: 2 \mathrm{M} 9 \mathrm{~N}=11, \sum=34, \dagger 1986$.

Kuigi nime sai vaid üks vallaline sulane (Jüri), levis see esialgu keskmiselt. Jüri viiest lapsest oli lapsi vaid ühel. 1930. aastatest fikseeriti nimekuju Limokas. Üks eestistas nime 1940 (> Laidala). Nimi hääbus meesliinide puudusel, kaks viimast nimekandjat surid 1972 ja 1986.

\subsection{Paks (1989: 30, 2021: 49)}

Algsel nimepanekul saadi nimi Paks kolmes Liivimaa mõisas, neist ühel puhul (20) talunime järgi. Ühel (19) nimi muutus, teisel (21) hääbus. Tänaseni (24 nimekandjat) on kestnud kolmanda sugukonna (20) nimi, kuigi esines ka nime muutmist XIX sajandil ja ühe korra eestistamise ajal. Kahel puhul $(17,18)$ ei ole õnnestunud välja selgitada nime tekkeaega 
ega hilisemat käiku. Kokku on aastani 1935 tuvastatud 140 nimekandjat, neist 127 ühest sugukonnast (20).

17. PE Petseri. Eksisteeris $1920, \sum=3$.

1917 lahkus Ilja Paks (1890-?) Petserist Venemaale ja 1920 soovis abikaasa ja pojaga opteeruda. Ema ja õed elanud tal tollal Petseris. Tema sündi kontrollida ei saa (kirikuraamatud pole säilinud), 1920-1923 Petseri linna elanike nimekirjades nime Paks ei esine. Nime Paks üldise nimepaneku ajal Petserimaal ei pandud.

18. TA Kambja Suure-Kambja. Eksisteeris $1878-1887, \sum=2$.

Nimi esineb 1852 nekrutiks võetud ja 1878 kogukonda sisse kirjutatud Bernhard Paksul ja 1887 soldatist naasnud Peeter Paksul. Teisi andmeid nende kohta pole õnnestunud leida. Tõenäoliselt on tegu mõne SuureKambja nime (Laks, Pales vmt) valesti kirjutamisega.

19. TA Kursi Laeva. 1826: $2 \mathrm{M} 3 \mathrm{~N}=5(\mathrm{~V}), \sum=7, \dagger 1859$.

Nime sai vabadikupere. Vanemad surid varakult, kolm tütart abiellusid, üks suri, ainsa poja nimi muutus esialgu hingeloendis, sealt 1859. aastal saadud andmete järgi ka kirikuraamatutes nimeks Luks (1858 Paks /heißt Luks/).

20. TA Rõngu Suure-Rõngu. [1826: $8 \mathrm{M} 7 \mathrm{~N}=15$ (PS)], 1870: $9 \mathrm{M} 15 \mathrm{~N}=24$, 1900: $15 \mathrm{M} 20 \mathrm{~N}=35,1935: 14 \mathrm{M} 13 \mathrm{~N}=27, \sum=127$.

Nimi pandi Paksu talu (1684 Paxe Tinn) pererahvale ja nende sugulastest sulastele mujal (kolme venna pered), kuigi kahe noorema, talust lahkunud venna pered said perekonnanime Treial. XIX sajandi keskpaiku sulasperel nimi varieerus (Pauks, Paaks, Saks), kuid vaid ühel korral. Püsivam muutus oli seal nimeks Pikk, kuid selle puhul taastati hoopis õige nimi, kuna tegu oli võõraspojaga (1862 Pik, hieß früher Paks), samas tema Venemaale rännanud järeltulijad kandsid edasi nime Paks. Seega esines nimeparandus kirikuraamatutes, kuid ei jõudnud hingekirjutuse dokumentidesse. 1900. ja 1935. aasta andmed võivad olla alahinnatud õigeusku ja Venemaale läinute tõttu. Eestistamise ajal üks inimene muutis nime (> Vaikla), põhjenduseks nime "halb tähendus“ (ERA.76.4.1632:156). Tõenäoliselt on kõik 24 praegust sellenimelist seotud siinse sugukonnaga.

21. VL Tarvastu Uue-Suislepa. [1826: 1N (S)], $\sum=1, \dagger 1834-1850$.

Vallaline tüdruk, kelle andmeid kirikuraamatutest ega hilisematest hingeloenditest pole õnnestunud leida (võimalik, et esineb teise perekonnanimega). 


\subsection{Ilus (1989: 135, 2021: 160; Illus 1989: 32, 2021: 43)}

Nimi pandi ühes Eestimaa ja neljas Liivimaa mõisas. Neli Liivimaa mõisa (Hls Kaarli ja Pst Õisu ning Rõn Hellenurme ja Ote Päidla) moodustasid omavahel kaks mõisakobarat, sealseid nimesaajaid on käsitletud koos. Ühel puhul (22) tekkis nimi 1870. aastail nimest Illust, kuid see hääbus. Viiest algsest sugukonnast kolmel nimi hääbus demograafilistel põhjustel, neljandas (26) on hääbumas. Nime võeti eestistamisel viiel korral ka uueks nimeks (vanad nimed Müller, Hilpus, Söön, Saeberg). Kahel korral Kambja vallas Mülleri nime vahetanutel võib olla seos Kaarli-Õisu või Patküla sugukonnaga, kelle esindajad samuti Kambjas elasid. Vana ja uue kirjaviisi nimekuju (Illus ja Ilus) pole töös eristatud. Kokku on aastani 1935 tuvastatud 467 nimekandjat, neist 397 ühest sugukonnast (23).

22. HA Hageri Kurtna. Eksisteeris vähemalt 1871-1917, 1900: 2N, $\sum=3$, $\dagger>1917$.

Kurtnast nekrutiks võetud Aadu Illust (1828-1888) kandis sõjaväest naastes hiljemalt 1871 Üksnurmes ja hiljem Tallinnas nime Illus. Tema ainsa tütre andmed pärast 1917 on teadmata.

23. PÄ, VL Halliste, Paistu Õisu, Kaarli. 1826: $21 \mathrm{M} 21 \mathrm{~N}=42$ (PS), 1870 : 49M45N = 94, 1900: $61 \mathrm{M} 58 \mathrm{~N}=119, \underline{1935}: 49 \mathrm{M} 64 \mathrm{~N}=113, \sum=397$.

Kaarli oli Õisu kõrvalmõis. Suur hulk esmaseid nimesaajaid tagas nime edasise leviku, kuigi suur osa olid sulaspered. Õigeusku mineku, Lätti ja Venemaale väljarändamise ning Paistu koguduse puudulike personaalraamatute tõttu on andmed alaesindatud. Nime varieerumist peale vanast uude kirjaviisi muutumise (Illus $>$ Ilus) pole teada. Leitud andmete järgi oli nime levik naisliinide tõttu vähenemas, mida kinnitavad ka andmed, et 1900-1934 sündinute hulgas oli 40 meest ja 45 naist.

24. TA Rõngu, Otepää Hellenurme, Päidla. 1826: 4M2N = $6(\mathrm{P}), \underline{1870}$ : $1 \mathrm{M} 1 \mathrm{~N}=2$, 1900: $3 \mathrm{M} 2 \mathrm{~N}=5, \sum=22, \dagger 1917$.

Päidla oli Hellenurme kõrvalmõis. Hingeloendites on nimi Illuse Illusse $\sim$ Illusa Illosa, kirikuraamatutes Illus, aluseks lisanimi Illusamoisa. Sugukonna kuuest täiseani jõudnud mehest viis surid vanuses 20-38 aastat ja üks 57 aastat. Viimasel nimekandjaid lapselapsi polnud. Viimane nimekandja oli lesknaine, kes abiellus uuesti.

25. VI Jõhvi Illuka. 1835: 1M (S), $\sum=2, \uparrow>1857$.

Tõenäoliselt sulase staatuses Jaak (1803-1858-?) sai perekonnanime, hiljem abiellus. Laste kohta andmed puuduvad, abikaasa suri enne teda. 
26. VL Helme Patküla. 1826: $2 \mathrm{M} 2 \mathrm{~N}=4(\mathrm{~S}), \underline{1870}$ : $3 \mathrm{M} 4 \mathrm{~N}=7, \underline{1900}$ : $5 \mathrm{M} 6 \mathrm{~N}=11, \underline{1935}: 4 \mathrm{M} 4 \mathrm{~N}=8, \sum=37$.

1826. aasta hingeloendis on naistel perekonnanimi Illis. Nime aluseks on nähtavasti talunimi Illise, kuid hiljem esineb vaid nimi Illus $\sim$ Ilus. Hetkel on nimekandjaid teadaolevalt kolm, kellelt nimi tõenäoliselt edasi ei kandu.

27. VÕ Karula Karula. 1826: $1 \mathrm{M}(\mathrm{S}), \sum=6, \uparrow>1857$.

Sulase Juhani poja Karli (1832-1858-?) kohta hilisemad andmed puuduvad, kuid samas kandis hiljem nime ei esine. Teisi nime võimalikke edasikandjaid polnud.

\subsection{Kuningas (1989: 328, 2021: 410)}

Nimi saadi alguses ühes Eestimaa ja kolmes Liivimaa mõisas, neist kahe puhul lisanime järgi. Kahel algsel sugukonnal $(34,35)$ hääbus nimi juba XIX sajandil. Kahel korral saadi nimi Petserimaal, ühe puhul võib olla nimi hääbunud. Rööpnimena tekkis ühel korral (32), hiljem see ainustus, kuid hääbus. Nimi on varieerunud vaid vana ja uue kirjaviisi tõttu (Kunningas $>$ Kuningas). Analüüsitud pole Uue-Lõve nime Kuning, mis on lühikest aega XX sajandi algul vaheldunud ka nimega Kuningas, kuid püsima jäi esimene nimekuju. Huvitav on, et kuigi nimi Kuningas ei olnud kaitseregistris ega laialt levinud nimede nimekirjas ${ }^{6}$, ei võetud seda eestistamisel kordagi, kuigi mõnel korral seda sooviti. Küll aga võeti nimi Kuning 1938 Tallinnas nime Hrisanfov asemele. Kokku on aastani 1935 tuvastatud 805 nimekandjat, neist 616 ühest sugukonnast (30). Praeguste nimekandjate hulgas võib olla ka Soome päritolu inimesi.

28. PE Pankjavitsa. $1935: 1 \mathrm{M}, \sum=3$.

Kiislova külas 1921 pandud nimi (tollal abielupaar vähemalt ühe pojaga - kõikide laste arv pole teada). Andmed ebatäielikud, kuid nimi võis hääbuda juba XX sajandi keskel.

6 1934. aastal sisse seatud perekonnanimede kaitseregister võimaldas tasu eest oma nime võtmist mittesugulastele keelata (RT 1934, 52, 438). Laialt levinud perekonnanimede nimekirja arvati esialgu (1934) eestipärased nimed, millel oli Tallinnas ja Tartus kokku üle 100 kandja, ning nimekirja plaaniti laiendada üle-eestiliseks, nii et see oleks hõlmanud üle 1100 nime (Lepp 1936: 265). Siis oleks sinna kuulunud ka Kuningas. Nimekiri hõlmas aga 1940. aastaks vaid 289 nime, sest 1935 ja 1938 lisati nimekirja üksnes need, mida eestistamisel liigselt sooviti võtta (RT 1935, 98, 806; RT 1938, 97, 840). 
29. PE Petseri. 1935: $3 \mathrm{M} 5 \mathrm{~N}=8, \sum=12$.

1921 said Veretino külas nime vanapaar kahe lapse, minia ja kahe lapselapsega (kokku 7). Praegu kümmekond nimekandjat.

30. PÄ Saarde Jäärja. 1826: 18M24N = 42 (PHSK), 1870: 46M50N = 96, 1900: $93 \mathrm{M} 96 \mathrm{~N}=189,1935: 91 \mathrm{M} 109 \mathrm{~N}=200, \sum=616$.

Nimi saadi talunime (võimalik, et ka lisanime) järgi (1684 SooKunigas). Nime said talurahva kõikide sotsiaalsete kihtide esindajad, kuid käsitöölise (rätsepa) nimeliinis järeltulijad hääbusid neljandas põlvkonnas ning ka sulase järeltulijaid oli vähe. Suur enamus on vendadest peremehe ja koolmeistri järeltulijad. Massilise õigeusku mineku ja kohatise väljarändamise tõttu on levik alaregistreeritud. Ka 1930. aastate andmed on ebatäielikud. Kuna tegu oli põliste talupidajatega, kannatasid pered palju 1940. aastate repressioonides. Silmatorkav on XIX sajandil paljude eakate ja mitu korda abiellunud meeste ning seega ka nende laste suur arv, kuid ka viimaste suremus (vt 3. peatükist). Mitmel korral abiellusid mees ja naine Kuningas, seega abielunaise neiupõlvenimi kandus edasi ka tema lastele.

31. VI Jõhvi Ohakvere. 1835: 4M7N = $11(\mathrm{P}), \underline{1870}: 8 \mathrm{M} 9 \mathrm{~N}=17, \underline{1900}$ : $15 \mathrm{M} 12 \mathrm{~N}=27,1935$ : $17 \mathrm{M} 23 \mathrm{~N}=40, \sum=99$.

Nime sai pererahvas, kuid laste suhteliselt suure suremuse tõttu nimi edenes aeglaselt. Näiteks kahes peres, kus 1908-1929 sündis kokku 14 last, suri neist 9. Praegu on ligikaudu paarkümmend nimekandjat.

32. VL Tarvastu Tarvastu. Eksisteeris 1886-1933, (1900: $2 \mathrm{M} 2 \mathrm{~N}=4), \sum=4$. Viljandi Uusnast pärit Märt Vasar (1852-1911) sai Tarvastus 1886 rööpnime Kuningas (1886 Wasar gnt Kuningas, 1915 Wasar al. Kuningas), tema poeg suri noorelt 1915, tütar abiellus 1916. Viimane nimekandja oli Märdi lesk Liis, kes suri 1933 nimega Kuningas.

33. VÕ Rõuge Saaluse. 1826: $1 \mathrm{M} 5 \mathrm{~N}=6(\mathrm{~S}), \underline{1870}: 6 \mathrm{M} 3 \mathrm{~N}=9$, 1900: $7 \mathrm{M} 5 \mathrm{~N}=12,1935: 8 \mathrm{M} 3 \mathrm{~N}=11, \sum=42$.

Sulaspere saadud nimi XIX sajandil küll levis, kuid XX sajandil taandus (vähemalt Eestis) naisliinide ning ühe nimemuutuse pärast: vallaspoeg Tannil (1842-?) sai pärast saksa koolis käimist (emaisa Jakobi järgi) nimeks Daniel Gustav Jakobson. Venemaale rändamise tõttu võivad 1900. ja 1935. aasta andmed olla alaregistreeritud. Tänapäeval on Eestis alla kümne nimekandja.

34. VÕ Rõuge Vana-Roosa. (1826: $4 \mathrm{M} 11 \mathrm{~N}=15(\mathrm{P})), \sum=27, \dagger 1840$.

Sugukonna kaks haru said kirikuraamatutes perekonnanime Kunningas, hingeloendites sai üks Langas ja teine 1826 Kunska, 1834 ja hiljem Künnapä. 1840 viis Rõuge pastor kirikuraamatute nimed kooskõlla 
hingeloendite nimedega (seda kõikide oma koguduseliikmete puhul). Kirikuraamatutes jõudsid Kuninga nime kanda 27 inimest.

35. VÕ Räpina Kahkva. 1826: $2 \mathrm{M} 2 \mathrm{~N}=4(\mathrm{P}), \sum=4, \dagger 1850-1858$. Perekonnanime sai lisanime järgi pererahvas (lell ja vennapoeg naistega), kes mõne aasta pärast jäid sulasteks (võimalik, et lastetuse tõttu). Kummalgi paaril nimesaamise ajal lapsi polnud, ei saa välistada väiksena surnud laste olemasolu. Viimane nimekandja, vennapoja lesk, suri vahemikus $1850-1858$.

\subsection{Tarkus (1989: 83, 2021: 75)}

Nimi saadi esimesena 1809. aastal Erastvere mõisas, kuna Kanepi kihelkonnas pandi perekonnanimed varem. Üldise nimepaneku ajal saadi veel ühes Liivimaa ja kahes Eestimaa mõisas. Viimastest ühel juhul oli tegu nähtavasti eksimusega ning peagi esines selle asemel parandatud Tarakus. XIX sajandi lõpul tekkis ühel puhul Tarkus ka teisest perekonnanimest, kuid see hääbus samas põlvkonnas. Teisi varieerumisi ei leitud, eestistamisel nime Tarkus ei võetud. Seega on algseid sugukondi kolm ning kõikides nendes on nimekandjaid ka praegu, pooltel juhtudel on need Erastvere sugukonnaga seotud inimesed. Kokku on aastani 1935 tuvastatud 295 nimekandjat.

36. SA Kärla Kärla. [1826: $7 \mathrm{M} 8 \mathrm{~N}=15(\mathrm{P})], \underline{1870}: 7 \mathrm{M} 13 \mathrm{~N}=20, \underline{1900}$ : $13 \mathrm{M} 9 \mathrm{~N}=22, \underline{1935}$ : $16 \mathrm{M} 23 \mathrm{~N}=39, \sum=101$.

Kuigi XX sajandi keskpaigani nimi levis, ei jätkunud edasine levik meesliinis samavõrra. 1900-1934 sündis 14 meest ja 13 naist, meestest kaks surid lapsena, viiel teadaolevalt lapsi ei olnud. Nõukogude perioodil võttis ühel puhul mees abielludes naise nime. Praegu on ligikaudu paarkümmend nimekandjat.

37. TA Tartu. 1900: $1 \mathrm{M} 1 \mathrm{~N}=2, \sum=4, \dagger 1924$.

Tartus elavale Johann Friedrich Tarosele (1836-1924) tekkis 1870. aastate paiku rööpnimi Tarkus (1874 Tarkus parandatud > Taros, 1883 Taros auch Tarkus). Kuna tal oli vaid kaks tütart, kes mõlemad abiellusid, hääbus nimi tema endaga (abikaasa suri 1912).

38. VI Haljala Vihula. $\underline{1835}: 5 \mathrm{M} 5 \mathrm{~N}=10(\mathrm{P}), \underline{1870}: 15 \mathrm{M} 15 \mathrm{~N}=30, \underline{1900}$ : $15 \mathrm{M} 17 \mathrm{~N}=32, \underline{1935}: 12 \mathrm{M} 13 \mathrm{~N}=25, \sum=97$.

Nimi levis XIX sajandil jõudsalt, kuid XX sajandi algul hakkas hääbuma väheste poegade või nende puudumise tõttu. 1900. ja 1935. aasta andmed võivad olla ühe perekonna Venemaale mineku tõttu veidi 
alaregistreeritud. Üllatav on mees- ja naisnimekandjate võrdne arv läbi aegade. Praegu on ligikaudu 15 nimekandjat.

39. VI Jõhvi Illuka. 1835: $3 \mathrm{M} 4 \mathrm{~N}=7$ (P), $\sum=7, \dagger 1835$.

Kuju Tarrkus esineb vaid 1835 perekonnanimede raamatus. Kirikuraamatutes on juba 1836 Tarrakus (< Tarakuste küla, sks Tarrakus, kus pere elas), nimi parandati ka järgmises hingeloendis. Pigem tuleb nime Tarrkus lugeda eksimuseks.

40. VÕ Kanepi Erastvere. 1809: $4 \mathrm{M} 2 \mathrm{~N}=6, \underline{1826}$ : 4M4N = 8 (P), 1870: $9 \mathrm{M} 9 \mathrm{~N}=18, \underline{1900}: 15 \mathrm{M} 13 \mathrm{~N}=28, \underline{1935}: 15 \mathrm{M} 19 \mathrm{~N}=34, \sum=86$.

Kuna Erastveres on erandina pandud perekonnanimi juba 1809, on esitatud ka selle aasta andmed. Nimi levis keskmiselt, kuid oluline oli piisav poeglaste arv XX sajandi algul. 1900-1934 sündinud lastest kümme olid poisid (neist suri lapsena kaks), kuus tüdrukud. Praegu on ligikaudu 40 nimekandjat ehk pooled kõikidest nime Tarkus kandjatest.

\subsection{Truumees (1989: 47, 2021: 49; Trumees 2021: 1; Trumes 2021: 5)}

Nimi pandi kahes Eestimaa ja neljas Liivimaa (Saaremaa) mõisas. MustaPussi andmebaasis olid Pöi Kingli ja Koigi mõisa andmed esitatud koos, kuid kontrollimisel selgus, et need on vaid Kingli mõisa nimed ja Koigis pandi samuti nimi Truumees. Kuuest sugukonnast kahes hääbus nimi aastaks 1935, neljas kestab edasi. Nimekuju on varieerunud vanas ja uues kirjaviisis: Trumees $\sim$ Trumes $\sim$ Truumees. Nime võeti kolmel korral ka eestistades, neist endise nime Vinter kandjad Saaremaal lahkusid Eestist II maailmasõja ajal, jõudes USAsse, kus nimi esineb praegugi. Truumees võeti ka Treumann $\sim$ Treimann asemele Tartus. Kokku on aastani 1935 tuvastatud 289 nimekandjat. Praegune nimekuju Trumes on seotud vahepeal Venemaal elamisega.

41. HA Jüri Rae, Kautjala. 1835: $2 \mathrm{M} 4 \mathrm{~N}=6$ (PS), $\sum=8, \uparrow 1865$.

Nime said kaks venda: vallaline mõisavaht Hans ja peremees Taavet (1801-1839). Viimasel oli viis tütart, kellest noorim abiellus 1865, ainus poeg suri lapsena.

42. JÄ Anna Purdi. 1835: $3 \mathrm{M} 4 \mathrm{~N}=7(\mathrm{~K}), \underline{1870}: 3 \mathrm{M} 1 \mathrm{~N}=4, \underline{1900}: 5 \mathrm{M} 3 \mathrm{~N}=8$, 1935: $5 \mathrm{M} 3 \mathrm{~N}=8, \sum=32$.

Nime sai rätsep perega. Esmastest nimesaajatest kandus nimi edasi järgmisse põlvkonda vaid Mardi (1826-1889) kaudu. Tema ühel pojal oli poeg (lastetu), teise poja 12 lapsest 11 surid imikuna. Praegu on ligikaudu viis nimekandjat ühest perest. 
43. SA Kaarma Kaarma-Suuremõisa. 1826: $6 \mathrm{M} 10 \mathrm{~N}=16(\mathrm{P}), \underline{1870}: 9 \mathrm{M} 6 \mathrm{~N}$ $=15, \underline{1900}: 23 \mathrm{M} 17 \mathrm{~N}=40, \underline{1935}: 16 \mathrm{M} 21 \mathrm{~N}=37, \sum=112$.

Õigeusu ja võimaliku väljarände (meremehed) tõttu on alaregistreeritud. Seetõttu võis meeste ülekaal ka XX sajandil II maailmasõjani jätkuda. Praegu on nimekandjaid vähemalt kümme.

44. SA Kihelkonna Karala. 1826: $11 \mathrm{M} 8 \mathrm{~N}=19(\mathrm{PV}), \underline{1870}: 1 \mathrm{M} 8 \mathrm{~N}=9$, 1900: $1 \mathrm{M} 3 \mathrm{~N}=4, \sum=38, \dagger 1913$.

Nime sai peamiselt pererahvas (kolme venna pered), sh suur hulk mehi. Kolme venna üheksast pojast oli lapsi vaid kahel, kolm poega surid noorelt, kolm võeti nekrutiks, ühel polnud lapsi. Nimi hääbus põlvkondade lõikes neljandas põlves, kus sündinud kuus last surid kõik imikuna (1859-1880, see oli ka viimane sünd). Viimane nimekandja oli leskmees Aadu (u 1828-1913).

45. SA Pöide Kingli. $\underline{1826}: 1 \mathrm{M} 3 \mathrm{~N}=4(\mathrm{P}), \underline{1870}: 4 \mathrm{M} 1 \mathrm{~N}=5, \underline{1900}: 4 \mathrm{M} 8 \mathrm{~N}$ $=12,1935: 6 \mathrm{M} 8 \mathrm{~N}=14, \sum=41$.

Nime sai noor peremees naise ja kahe õega. Peremehe kolmest pojast ühel olid järeltulijad (neli poega, nendest kahel on praeguseks nimekandjatest järeltulijaid). Hingeloendis 1826 Trumees, 1834-1858 Treu, kirikuraamatutes 1836, 1839 Tru, 1840 Trei > Tru, 1859 Трумеесъ. 1873-1891 peetud vallaliikmete nimekirjas oli alguses Tru, hiljem parandatud Trumees. Praegu on kümmekond nimekandjat.

46. SA Pöide Koigi. [1826: $10 \mathrm{M} 6 \mathrm{~N}=16(\mathrm{P})], \underline{1870}: 4 \mathrm{M} 2 \mathrm{~N}=6, \underline{1900}: 6 \mathrm{M} 7 \mathrm{~N}$ $=13, \underline{1935}: 4 \mathrm{M} 10 \mathrm{~N}=14, \sum=58$.

Kuigi nime said mh kuus alaealist meest, surid kolm neist lasteta. Õigeusku ja Venemaale mineku tõttu võib olla alaregistreeritud. Praegu on vähemalt kümmekond nimekandjat.

\section{Analüüs}

Valitud kaheksa nime esinesid 46 sugukonnas või perekonnas, millest negatiivse konnotatsiooniga neli nime esinesid 21 korral kokku 560 kandjaga (keskmiselt 27 kandjat sugukonnas) ning positiivse konnotatsiooniga neli nime 25 korral kokku 1856 nimekandjaga (keskmiselt 74 kandjat sugukonnas). Siiski võis suhteliselt väikese valimi tõttu positiivse konnotatsiooniga nimede kandjate suur hulk olla mõjutatud kahest väga suurest sugukonnast - Ilus (23) ja Kuningas (30) -, milles oli kokku 1013 kandjat (kahe sugukonna keskmine 507). 
Negatiivse konnotatsiooniga nimesid kandnud sugukondi iseloomustab nime algsete saajate väike keskmine hulk (kokku 68 saajat 16 sugukonnast, ühe sugukonna keskmine 4,3; algsete nimede hulka on arvatud ka nr 11). Meeste ja naiste suhe oli tasakaalus (35M ja 33N). Nimesaajate sotsiaalne staatus oli 12 korral talupoegade alamkiht (sulased ja vabadikud) ning neljal korral ülemkiht (pererahvas, lisaks sulased), viimastest kahel korral oli nime motiiviks talunimi $(11,20) .16$ algsest sugukonnast kuues hääbus nimi aastaks 1870 ning veel neljas aastaks 1900 (kokku 63\%), kolmel hääbus XX sajandi keskel (1935 veel esines), ühel aastal 1986 ning kahel $(11,20)$ pole hääbunud. Mõlemad praegugi nime kandvad sugukonnad olid nimesaamise ajal samanimelise talu pererahvas. Hiljem tekkinud nimedest on hääbunud kõik viis, seega neid arvestades on praeguseks alles 10\% vaadeldud negatiivsetest nimedest ning hääbunud $90 \%$.

Algsest 16 nimest hääbus 14, millest viiel korral (36\%) oli tegu onomastilise põhjusega, hiljem tekkinud nimedega koos (19 hääbunud nime) oli onomastiline põhjus seitsmel korral (37\%). Kõikidest hääbunud nimedest üheksal korral (47\%) oli põhjus demograafiline, ühel korral (8) mõlemad (sugukonna ühel harul onomastiline, teisel demograafiline), kahel $(17,18)$ pole nime saatus teada ning nimi eksisteeris vaid lühikest aega (seega pigem võiks hääbumise korral lugeda põhjuseks onomastilise, kuna nime kandnud inimesed elasid tõenäoliselt edasi). Demograafilise hääbumise põhjus oli enamasti vähene algsete nimesaaja hulk: kuuel korral sai nime vaid üks inimene, kes neljal korral jäigi ainsaks, ning nimi hääbus koos nendega XIX sajandi keskpaiku. Ühel korral sai ühest algsest nimekandjast kokku neli, vaid ühel korral sai 1900. aastaks 13, kuid nimi hääbus sellegipoolest. Viiel korral tekkis negatiivse konnotatsiooniga nimi algsest nimepanekust hiljem, neist neljal korral vaid üksikutele inimestele, ühel korral (7) kolmekümneks aastaks rööpnimena 28 inimesele.

Positiivse konnotatsiooniga nimede saajaid iseloomustab suur algsete nimesaajate hulk (kokku 238 saajat 20 sugukonnast, ühe sugukonna keskmine 11,9). Naisi oli meestest oluliselt rohkem (vastavalt 128 ja 110). Positiivse nime saajate sotsiaalne staatus oli viiel korral alamkiht (lisaks käsitöölised), 15 korral ülemkiht (lisaks nende sugulased teistest kihtidest) ehk suhe on täpselt vastupidine võrdluses negatiivse nime saajatega. Üks esmane nimesaaja oli vaid kahes sugukonnas.

Kuuel korral hääbus nimi 1870. aastaks, neist kahel korral onomastilistel põhjustel, kuigi siin on tegu hääbumisega vaid tinglikult. Nimelt 
ühel juhul viidi nimi kirikuraamatus vastavusse hingeloendi nimega (34) ja teisel juhul (39) parandati ilmselt kirjutusviga. 1900. aastaks rohkem nimesid ei hääbunud, 1935. aastaks hääbus demograafilistel põhjustel veel kaks algset nime ning kolm hiljem tekkinud nime. Ülejäänud 12 algset nime ehk 48\% (koos hiljem tekkinutega 13 ehk 52\%) esinesid aastal 1935 ja kõikides nendes sugukondades kestab nimi praegugi, ühel puhul (28) pole nime saatus selge.

XIX sajandi lõpupoole tekkis positiivseid nimesid kolmel korral teise nime kõrvale (37) või asemele (22, 32), kuid kõik need hääbusid enne 1935. aastat. Kahel korral pandi positiivne nimi Petserimaal 1921. aastal, neist ühel juhul hääbus, teisel (28) pole teada.

Negatiivse ja positiivse konnotatsiooniga nimede võrdlusena saab esile tuua järgmist. Algselt said negatiivse nime positiivsega võrreldes sagedamini üksikud ja/või alamkihtidest inimesed, mis edaspidi mõjutas ka nime püsimist. Negatiivsete nimede saajate hulgas esinenud meeste ülekaalu võis põhjustada asjaolu, et negatiivse nime said sagedamini vallalised alamkihi mehed, kellel polnud õnnestunud abielluda. Positiivse nimega olid enamasti ülemkihi mehed, kellel oli ka abikaasa. Vastavalt hilisem või varasem abiellumine oli otseses seoses laste arvuga, mis on nime püsimisel esmatähtis.

Negatiivse nime esmasaajate keskmine arv sugukonna kohta oli üle poole väiksem positiivsete omast. Yasuda jt (1974: 137) on Itaalia puhul leidnud, et esmaste nimekandjate arv oli edasise arengu suhtes määrava tähtsusega: ühe esmakandjaga perekonnanimedest suri 300 aasta jooksul välja 80\%, nelja ja viie kandjaga 50\%, kümne kandjaga 0\% ning kokkuvõtlikult üle kuue kandjaga nimedest keskmiselt 17\%. Oluline on märkida, et uuritava andmestiku puhul oli nimede muutumine väga harv (samas: 133), mida ei saa aga öelda Eesti nimede kohta.

Kuna siinses töös ei olnud uuritavate nimede valik juhuslik, ei saa tulemusi üldistada kõikidele Eesti nimedele, kuid näitajad on Yasuda andmetega sarnased. Subjektiivselt valitud nimede ja vaatlusaluse perioodi200 aastat - puhul selgus, et ühe esmakandjaga nimedest hääbus 8/8 ehk 100\%, nelja ja viie kandjaga 5/7 (71\%), üle kuue kandjaga 7/19 (37\%), kümne kandjaga siiski 1/2 (50\%). Jättes välja onomastilisel põhjusel hääbunud nimed, mida Yasuda uuringus peaaegu ei leidunud, on tulemused tema andmetega veelgi lähedasemad (vt tabel 1). 
Tabel 1. Hääbunud nimede arv esmakandjatest lähtudes (\%)

\begin{tabular}{|l|c|c|c|c|}
\hline Alus & $\mathbf{1}$ & $\mathbf{4 - 5}$ & $\mathbf{1 0}$ & $\mathbf{6 +}$ \\
\hline Yasuda & 80 & 50 & 0 & 17 \\
\hline Kõik uuritud nimed & 100 & 71 & $50^{*}$ & 37 \\
\hline $\begin{array}{l}\text { Demograafilisel põhjusel } \\
\text { hääbunud nimed }\end{array}$ & 100 & 33 & $50^{*}$ & 25 \\
\hline
\end{tabular}

* Hääbus üks nimi kahest ning hääbunud nimel oli ühel harul demograafilised, teisel onomastilised hääbumispõhjused. Onomastilisi põhjusi arvestamata võib nimi olla mittehääbunud (lähtuvalt uurimisülesandest neid andmeid ei kogutud) ehk hääbumiste arv null.

Kuigi valikus olnud nimedest hääbus ühe esmakandjaga nimi olenemata konnotatsioonist, ei olnud see tegelikult alati nii. Näiteks 1870 . aastal tekkis Tallinnas üksikule soldatile Aadu Kehtile rööpnimi Aitsen ning nüüd kannab seda nime tema 43 järeltulijat ja nendega seotud inimest (Puss jt 2014).

Negatiivne nimi hääbus ligi kaks korda sagedamini kui positiivne ehk algsetest negatiivsetest nimedest jäi alles 13\% (koos hiljem tekkinutega 10\%) ning algsetest positiivsetest 48\% (koos hiljem tekkinutega 52\%). Veidi enam kui igal kolmandal negatiivsel nimel oli hääbumise põhjus onomastiline ehk nime muutus, igal teisel demograafiline. Hääbunud positiivsetest nimedest oli hääbumisel onomastiline põhjus (seda siiski tinglikult, vt eestpoolt) igal kuuendal. Ühe positiivse nime (33) puhul ei toonud nimemuutus (saksastamine) kaasa küll nime hääbumist, kuid näitab, et ka positiivne nimi ei olnud selle eest kaitstud. Valdavalt oli positiivsete nimede hääbumise põhjus siiski demograafiline. (Vt tabel 2 ja joonis.)

Enne demograafilist üleminekut oli kõrgemate sotsiaalsete kihtide esindajatel keskmiselt rohkem lapsi võrreldes madalate kihtide omadega. Eri ühiskondade ning perioodide andmeid kokku võttes on Skirbekk (2008: 155) leidnud, et Euroopas ja Põhja-Ameerikas langes kõrgemate sotsiaalsete kihtide fertiilsus madalamate omast allapoole XVIII sajandi keskpaiku, Aasias, Aafrikas, Ladina-Ameerikas ja Kaug-Idas aga XX sajandil.

XVIII-XIX sajandi Hiina perekondi uurides leiti, et kõrgkihi perekondadel ei olnud alamkihtidega võrreldes nimekandjatest järeltulijaid 
Tabel 2. Negatiivse ja positiivse konnotatsiooniga nimede võrdlus*

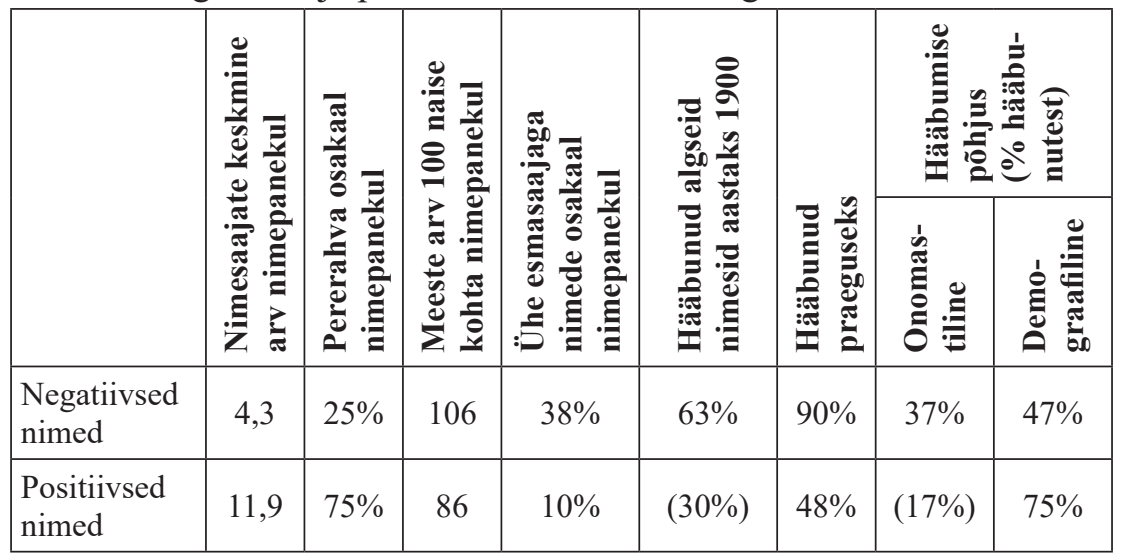

* Nimepaneku all on mõeldud üldist perekonnanimede panekut 1822-1835. Sulgudes on toodud andmed, mis on tinglikud (vt positiivsete nimede ülevaade lk 221-222).

rohkem, kuid nende suremus oli väiksem ning seetõttu nende osakaal rahvastikust kasvas enam. 150 aasta möödudes olid kõrgkihi perekondadest meesliinis (seega ka perekonnanimede liinis) hääbunud pooled, alamkihi omadest aga 3/4, kuna n-ö esiisa sotsiaalse staatuse mõju meesliini püsivusele kestis läbi põlvkondade. (Song jt 2015: 586-587, 594)

Eesti XVIII sajandi maarahvastiku kohta on teada, et pererahva ehk sotsiaalselt kõrgema kihi hulgas oli suurem abielulisus kui vabadike ja sulaste hulgas (Palli 1997: 43-44) ning seega oli pererahval ka suurem tõenäosus lapsi saada. Vastavaid andmeid Eesti kohta uuritaval perioodil (1820.-1930. aastad) siinkirjutajal teada pole. Võib aga eeldada, et pärisorjuse kaotamine ja talude päriseksostmine esialgu pigem suurendasid pererahva fertiilsust ning alles haridustaseme tõus (esialgu kirjaoskuse näitel) ja maaharitlaskonna tekkimine XIX sajandi viimaseks veerandiks (Elango jt 2010: 117-119) võisid kaasa tuua demograafilise ülemineku Eesti talurahva hulgas. Lugemisoskus oli juba XVIII sajandil pererahval peaaegu kaks korda suurem kui alamkihtidel ning ka pererahva rahvastikutaaste kordajad olid alamkihtide omadest suuremad (Palli 1997: 48-50, 53, 101-104). Kogu Eesti elanikkonda arvestades toimus demograafiline üleminek ehk kahelapselise perekonna ja laste väikese suremuse prevaleerimine Euroopaga võrreldes üsna varakult ning selle taga on peamiselt 1880.-1890. aastail sündinud naised (Gortfelder, Puur 2019). 


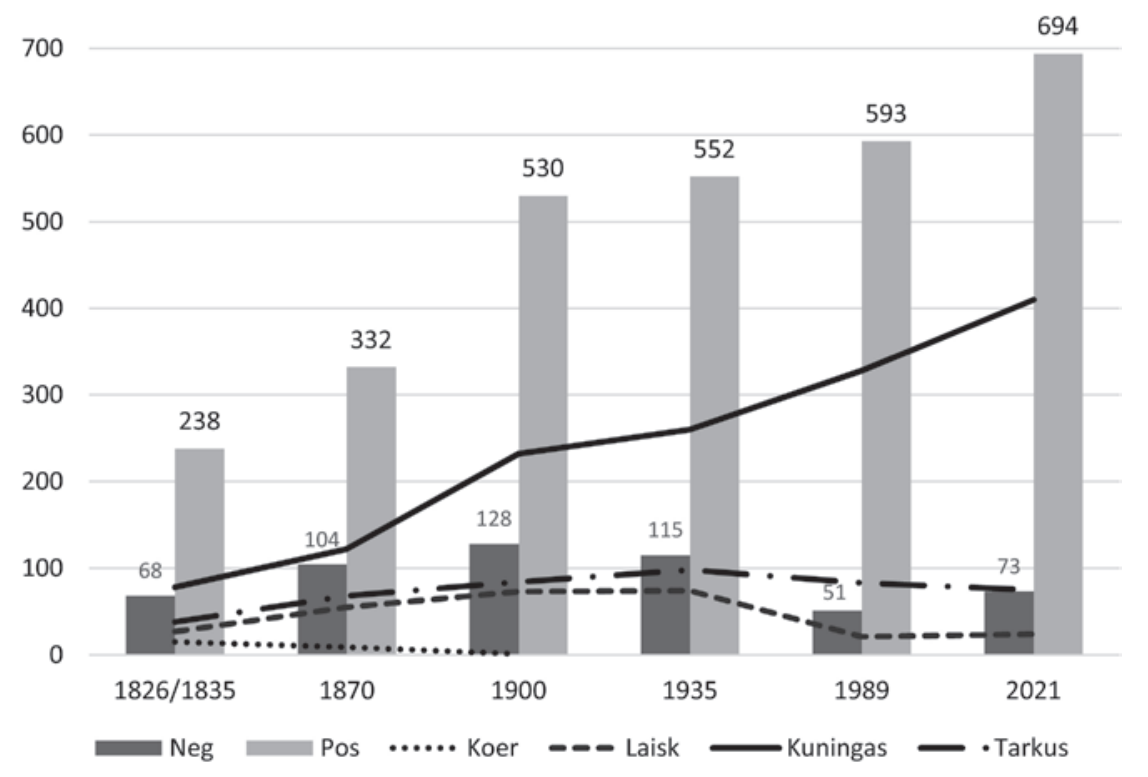

Joonis. Negatiivse ja positiivse konnotatsiooniga nimede kandjate koguarvu ning valitud nimede dünaamika

Kui demograafilise ülemineku ajaks ei olnud perekonnanimi juba piisavalt levinud, oli selle edasine levik varasemast raskem. Seega oli positiivsetel nimedel negatiivsete ees kaks eelistegurit: positiivsed nimed pandi pigem pererahvale (tulemus: rohkem lapsi) ning suuremale arvule esmakandjatele (tulemus: suurem tõenäosus nime püsimiseks). Negatiivne nimi ei olnud nähtavasti takistuseks pere loomisel, vaid nime püsimiseks oli olulisem nimekandja sotsiaalne staatus. Sotsiaalse staatuse tõusuga omakorda loobuti negatiivsest nimest enam. Hilisem demokratiseerumisprotsess võimaldas nimede eestistamisel nime muuta kõikidel soovijatel ning riigipoolse soodustuse tõttu (alates 1935. a) said seda teha ka väiksema sissetulekuga inimesed.

Sotsiaalset mobiilsust Eesti talurahva hulgas on XIX sajandi esimesel poolel hinnatud väikeseks (Kahk, Uibu 1980: 60-61) ning on leitud, et XIX sajandi keskpaiku ja teisel poolel sotsiaalsete klasside piirid süvenesid veelgi (Rosenberg 2010: 131). Samas põhjalikumad allikakriitikast 
lähtuvad uuringud teema kohta puuduvad ning nagu ka Klesment ja Lust (2021: 27) viitavad, suurenes rahvaarvu kasvuga ka maatute arv, järelikult oli suurem liikumine allapoole. Siinse uuringu eesmärk ei olnud jälgida sotsiaalse staatuse muutust, vaid ainult perekonnanime saamise hetke, kuigi staatus mõjutas nimede levikut otseselt ka edaspidi.

Nimede demograafiline hääbumine sõltus peale sotsiaalse staatuse ja laste arvu palju ka konkreetsest sugukonnast. Laste ellujäämuses on sugukonniti erisusi, mille põhjuseid tuleb otsida geneetikast, elutingimustest vm. Töö eesmärk polnud välja selgitada sugukondade demograafilisi näitajaid, kuid võimalik on teha mõningaid üldistusi selle kohta, mis nimede püsimust mõjutasid.

Kahes suurimas uuritud sugukonnas oli laste suremus väga erinev. Jäärja Kuningate sugukonnas (30) aastail 1840-1869 sündinud 99 lapsest, kelle eludaatumid on teada, suri hiljemalt viiendal eluaastal 38 (38\%) ning lisaks hiljemalt 20. eluaastal kaheksa (8\%), kokku enne tavapärast lastesaamisiga 46\%. Õisu Ilusate sugukonnast (23) 1840-1869 sündinud 78 lapsest, kelle eludaatumid on teada, suri hiljemalt viiendal eluaastal $13(17 \%)$ ning lisaks hiljemalt 20. eluaastal kolm (4\%), kokku enne tavapärast lastesaamisiga $21 \%$. Kuigi toodud numbrid pole täielikud, sest õigeusku läinud peredes võis lapsena surnuid olla seni registreerituile lisaks, suurendades lapsena surnute osakaalu veelgi, oli õigeusku läinuid mõlemas sugukonnas ning seetõttu on üle kahekordne laste suremuse erinevus naaberkihelkondade kahe valdavalt pererahvast sugukonna puhul märkimisväärne.

Heldur Palli (1997: 94-98) andmeil suri talurahva hulgas XVIII sajandi neljandal veerandil viiendaks eluaastaks 36-53\% lastest, olenevalt nende eluajal toimunud epideemiatest. XIX sajandi kohta on kokkuvõtlikud võrdlusandmed talurahva kohta napid. Perioodi 1840-1869 jäävad 1840. aastate ikaldusaastad ning suremust suurendasid eelkõige toidunappuse tagajärjel kergemini levinud nakkushaigused. Nende mõju ei olnud Lemming Rootsmäe andmeil (1987: 41-42) Pärnumaal võrreldes Eesti teiste piirkondadega keskmisest suurem. Helme ja Paistu kihelkonna kohta on Klesment ja Lust (2021: 31) leidnud, et aastail 1844-1846 oli seal küll suremus vanuserühmas 5-55 aastat suurem, kuid vanuserühmas 1-4 aastat ei olnud see märkimisväärselt erinev teiste perioodide omast ning enne viiendat eluaastat suri aastail 1834-1884 umbes 30\% lastest, pererahva hulgas veidi vähem kui maata kihis. Sellega võrreldes oli Kuningate 
sugukonnas laste suremus võrreldes sama piirkonna keskmisega oluliselt suurem, Ilusate sugukonnas aga oluliselt väiksem. See mõjutas ka otseselt perekonnanime edasi kandumist. Kuningate suure sugukonna nimekandmist see üldpildis ei mõjutanud, kuid väiksemate sugukondade puhul oleks see võinud viia nime hääbumiseni. Näiteks Purdi Truumeeste (42) puhul suurimas, 12 lapsega peres suri imikuna 11 last ning see mõjutas nime edasist levikut oluliselt.

Väiksema sugukonna puhul võisid olla määravad ka põlvkondade sünniaastad. Kui paljude perede lapsed sündisid 1890. aastail ja nende lapsed omakorda 1920. aastail, siis suur osa mõlema põlvkonna meestest hukkus või kaotas tervise vastavalt I maailmasõjas ja Vabadussõjas ning II maailmasõjas ja sellele järgnenud sündmustes (repressioonid, metsavendlus). Samuti mõjutas meesliinis järeltulijate hulka sõjaväeteenistus, sest nekrutikohustuse ajal naasis kodumaale vaid alla 20\% nekrutitest (Tannberg 2011:231). Uuritud sugukondades leidus selliseid, kus esimestes perekonnanime kandnud põlvkondades võeti mitu poega nekrutiks. Nekrutikohustusest olid vabastatud näiteks taluperemehed (aastani 1861 ka nende vanemad pojad) ja mõisateenijad (Tannberg 2011: 229, 247), samuti oli pererahval suurem võimalus end nekrutist vabaks osta. Mõjuta ei olnud isegi elukoht: kroonumõisades oli imikute ja väikelaste suremus lausa veerandi jagu väiksem kui eramõisades (Klesment, Lust 2021: 37).

\section{Kokkuvõte}

Perekonnanimesid on aja jooksul tekkinud ja hääbunud ning uurimuses analüüsitakse, kas emmale-kummale protsessile aitas kaasa nime negatiivne või positiivne konnotatsioon. Selgitati välja nelja negatiivse (Koer, Laisk, Limukas, Paks) ja nelja positiivse (Ilus, Kuningas, Tarkus, Truumees) konnotatsiooniga perekonnanime kõik võimalikud kandjad aastani 1935. Andmed on esitatud sugukonniti, saamaks ülevaadet, millised muutused toimusid perekonnanimede kandjate hulgas ning mis olid nime võimalikud muutused vastavas sugukonnas.

Negatiivse konnotatsiooniga sugukondade (kokku 21) puhul selgus, et tegu on valdavalt talurahva alamkihile (sulased ja vabadikud) ning väikestele perekondadele või üksikutele (keskmiselt 4,3 inimest) pandud nimedega. Aastaks 1900 hääbus 62\% vaadeldud negatiivsetest nimedest, XX sajandi keskpaigaks veel $19 \%$ ning praegu on alles vaid $10 \%$. 
Positiivse konnotatsiooniga nimed esinesid enamasti pererahval ning olid suurema esmakandjate arvuga (keskmiselt 11,9). Sisuliselt hääbus algselt saadud positiivsetest nimedest saja aasta jooksul vaid kaks (8\%), formaalselt veel kaks. Hiljem tekkinud nimedest hääbus kolm. Positiivsete nimede puhul on alles $48 \%$ algselt saadud nimedest, $52 \%$ koos hiljem saadud nimedega.

Negatiivsed nimed hääbusid kiiremini ja neli korda suurema tõenäosusega kui positiivsed ning sellel olid järgmised põhjused (tähtsuse järjekorras).

1. Negatiivsete nimede esmakandjate väike arv. Kuna ühe esmasaajaga nime puhul on hääbumise tõenäosus väga suur (vaadeldud nimedest $100 \%$, sh $88 \%$ järgnenud poolsajandi jooksul), hääbusid kiiremini negatiivsed nimed. Esmasaajate suurem hulk aitaks nime laiemale levikule kaasa olulisel esimesel poolsajandil.

2. Hilisemad demograafilised põhjused, mis olid omakorda tingitud nimekandjate sotsiaalsest staatusest, mitte aga nime varjundist. Kuna negatiivse nime saajaid olid enam alamkihtidest, oli neil enne demograafilist üleminekut, mis Eestis toimus XIX-XX sajandi vahetuse paiku, väiksem abiellumus ning väiksem laste arv. See soodustas nime hääbumist. Positiivsed nimed saanud pererahval oli omakorda enne demograafilist üleminekut rohkem lapsi, mis tagas nime laiema leviku.

3. Onomastilised põhjused, mis viisid 33\% negatiivsete nimede hääbumiseni. Nimi muutus enamasti hiljemalt XIX sajandi viimasel veerandil. Positiivsed nimed muutuste tõttu ei hääbunud, kuigi ka nende hulgas tuli muutusi ette.

4. Individuaalsed põhjused. Mõnes sugukonnas oli laste suurem suremus ja tütarde suurem hulk või sattusid põlvkonnad perioodi, mil mehed võeti sõtta. Väikeste sugukondade puhul võis iga eelnimetatud kriteerium olla nime levikule olulise mõjuga.

Nii negatiivseid kui ka positiivseid nimesid tekkis üksikjuhtudel ka pärast üldist nimepanekut rööpse perekonnanimena ning mõlemad läbisid ka muutusi. Kuigi uuritud näidetes ükski negatiivne nimi ei hääbunud nimede eestistamisel täielikult (küll aga mõjutas see nime levikut), võis see teiste negatiivsete nimede puhul juhtuda.

Väljatöötatud meetodit saaks edaspidi kasutada ka piirkondliku uurimusena, olenemata perekonnanime konnotatsioonist. Praegu puudub 
ülevaade, kui palju Eestis saadud nimedest oli üldse negatiivse, positiivse või neutraalse konnotatsiooniga. Piirkondliku uurimuse, nimede konnotatsioonide ja käesoleva uurimuse kombinatsioonina saaks teha järeldusi ka selle kohta, kui palju 1820.-1830. aastail saadud nimedest on üldse XX sajandini või tänapäevani jõudnud.

\section{Kirjandus}

Bacaër, Nicolas 2011. A Short History of Mathematical Population Dynamics. London: Springer-Verlag.

EKNR = Marja Kallasmaa, Evar Saar, Peeter Päll, Marje Joalaid, Arvis Kiristaja, Enn Ernits, Mariko Faster, Fred Puss, Tiina Laansalu, Marit Alas, Valdek Pall, Marianne Blomqvist, Marge Kuslap, Anželika Šteingolde, Karl Pajusalu, Urmas Sutrop 2016. Eesti kohanimeraamat. Tallinn: Eesti Keele Sihtasutus.

Elango, Aleksander, Endel Laul, Allan Liim, Väino Sirk 2010. Eesti kooli ajalugu. 2. köide: 1860. aastaist 1917. aastani. Tallinn: Teaduste Akadeemia Kirjastus.

Gortfelder, Mark, Allan Puur 2019. Demograafiline nüüdisajastumine Eestis: 1850-1899 sündinud naiste emaduslugude analüüs. - Tuna 1, 19-38.

Hanks, Patrick, Richard Coates, Peter McClure 2016. The Oxford Dictionary of Family Names in Britain and Ireland. Vol. 1: Aaron-Cushing. Oxford, New York: Oxford University Press.

Hupel, August Wilhelm 1818. Ehstnische Sprachlehre für die beyden Hauptdialekte, den revalschen und dörptschen, nebst einem vollständigen ehstnischen Wörterbuche. Zweyte durchgängig verbesserte und vermehrte Auflage. Mitau: J. F. Steffenhagen und Sohn.

Jaago, Tiiu, Kalev Jaago 1996. See olevat olnud .... rahvaluulekeskne uurimus esivanemate lugudest. Tartu: Tartu Ülikooli Kirjastus.

Johansen, Ulla 1998. Linnaeestlaste sugulussuhted. - Akadeemia 3, 451-487.

Kahk, Uibu 1980 = Юхан Кахк, Халлики Уйбу 1980. О социальной структуре и мобильности эстонского крестьянства в первой половине XIX века. Таллинн: Ээсти Раамат.

Klesment, Martin, Kersti Lust 2021. Short-term economic stress and mortality differentials in rural Estonia, 1834-1884. - Scandinavian Economic History Review 69 (1), 22-40. https://doi.org/10.1080/03585522.2020. 1739121

Lepp, A. 1936. Perekonnanimede statistika. - Eesti Statistika 5, 264-267.

Must, Aadu 2000. Eestlaste perekonnaloo allikad. 2., parand. ja täiend. tr. Tartu: Ajalookirjanduse Sihtasutus „Kleio“. 
Must-Puss $=$ Onomastika andmebaas. Aadu Musta poolt 1995-1999 koostatud perekonnanimede paneku ja eestistamise andmed. Täiendanud Fred Puss 2000-. Fred Pussi valduses.

Palli, Heldur 1997. Eesti rahvastiku ajalugu 1712-1799. Tallinn: Teaduste Akadeemia Kirjastus.

Pankratov, Vasili, Francesco Montinaro, Alena Kushniarevich, Georgi Hudjashov, Flora Jay, Lauri Saag, Rodrigo Flores, Davide Marnetto, Marten Seppel, Mart Kals, Urmo Võsa, Cristian Taccioli, Märt Möls, Lili Milani jt 2020. Differences in local population history at the finest level: The case of the Estonian population. - European Journal of Human Genetics 28 (11), 1580-1591. https://doi.org/10.1038/s41431020-0699-4

Peil, Tiina 1999. Islescapes: Estonian Small Islands and Islanders Through Three Centuries. (= Stockholm Studies in Human Geography 8.) Stockholm: Almqvist \& Wiksell International.

Puss, Fred 2020. Muuga või Kersna? Eesti rööpsete perekonnanimede teke ja kadu. - Eesti ja soome-ugri keeleteaduse ajakiri. Journal of Estonian and Finno-Ugric Linguistics 11 (1), 43-85. https://doi.org/10.12697/ jeful.2020.11.1.03

Puss, Fred, Martin Ellermaa, Andry Arro, Milan Pening 2014. Aitsen 00619. Perekonnalooline uurimus. Käsikiri. Tartu: Eesti Isikuloo Keskus.

Redmonds, George 2016. Personal names and genealogy. - The Oxford Handbook of Names and Naming. Ed. by Carole Hough. (= Oxford handbooks in linguistics.) Oxford: Oxford University Press, 279-291. https://doi. org/10.1093/oxfordhb/9780199656431.013.30

Redmonds, George, Turi King, David Hey 2011. Surnames, DNA, and Family History. Oxford: Oxford University Press.

Rootsmäe, Lemming 1987. Nakkushaigused surma põhjustena Eestis 1711-1850. Tallinn: Valgus.

Rosenberg, Tiit 2010. Muutused maaühiskonnas. - Eesti ajalugu. V. Pärisorjuse kaotamisest Vabadussõjani. Toim. Andres Andresen jt. Tartu: Ilmamaa, 130-149.

RT $=$ Riigi Teataja, RT 1934, nr 52; 1935, nr 98; 1938, nr 97.

Skirbekk, Vegard 2008. Fertility trends by social status. - Demographic Research 18 (5), 145-180. http://dx.doi.org/10.4054/DemRes.2008.18.5

Song, Xi, Cameron D. Campbell, James Z. Lee 2015. Ancestry matters: Patrilineage growth and extinction. - American Sociological Review 80 (3), 574-602. https://doi.org/10.1177\%2F0003122415576516

Tannberg, Tõnu 2011. Eesti mees Vene kroonus. Uurimusi Baltikumi ja Venemaa sõjaajaloost impeeriumi perioodil 1721-1917. (= Ilmatargad.) Tartu: Ilmamaa. 
Tulva, Taimi, Lia Murs 2004. Põlvkondadevaheline sidusus genealoogia taustal. - Vananemine ja põlvkondadevaheline sidusus: teadusartiklite kogumik. Toim. Taimi Tulva. Tallinn: Tallinna Pedagoogikaülikool, 7-26.

Wiedemann, Ferdinand Johann 1973 [1893]. Eesti-saksa sõnaraamat. Neljas, muutmata trükk teisest, Jakob Hurda redigeeritud väljaandest. Tallinn: Valgus.

Yasuda, N., L. L. Cavalli-Sforza, M. Skolnick, A. Moroni 1974. The evolution of surnames: An analysis of their distribution and extinction. - Theoretical Population Biology 5 (1), 123-142. https://doi.org/10.1016/00405809(74)90054-9

\section{Rahvusarhiivi allikad}

EAA.1865.2.7/8. Vana-Kuuste mõisa hingeloend. 1826.

ERA.76.4.1552. Kohtuministeeriumi nimemuutmiste kontroll-lehed, LahtmäeLaiuste. 1935-1940. Pagineerimata.

ERA.76.4.1632. Kohtuministeeriumi nimemuutmiste kontroll-lehed, PaisbergPalderment. 1935-1940. Pagineerimata. 
Lisa. Analüüsitud 46 sugukonna koondandmed. Lühendeid vt lk 207-208

\begin{tabular}{|c|c|c|c|c|}
\hline $\mathrm{Nr}$ & Nimi & $\begin{array}{l}\text { Maakond, } \\
\text { kihelkond }\end{array}$ & $\begin{array}{l}\text { Mõis } \\
\text { (vald) }\end{array}$ & $\begin{array}{c}1826 / 1835 \\
\text { nimesaajaid }\end{array}$ \\
\hline 1 & Koer & HA Rap & Raikküla & 1 \\
\hline 2 & Koer & PÄ Vän & Vändra & 2 \\
\hline 3 & Koer & SA Krj & Roobaka & - \\
\hline 4 & Koer & TA San & Keeni & 5 \\
\hline 5 & Koer & TA Äks & Sootaga & 7 \\
\hline 6 & Koer & VL Hel & Leebiku & - \\
\hline 7 & Koer & VL Vil & Vana-Tänassilma & - \\
\hline 8 & Laisk & JÄ Ann & Purdi & 10 \\
\hline 9 & Laisk & SA Kär & Paadla & 1 \\
\hline 10 & Laisk & SA Muh & Kapi & 4 \\
\hline 11 & Laisk & TA Äks & Maramaa & 6 \\
\hline 12 & Laisk & VI Kad & Kolu & 1 \\
\hline 13 & Laisk & VL Pst & Holstre & 5 \\
\hline 14 & Limukas & HA Kos & Oru & 1 \\
\hline 15 & Limukas & TA Ksi & Saduküla & 3 \\
\hline 16 & Limukas & VL Plt & Vana-Põltsamaa & 1 \\
\hline 17 & Paks & PE & Petseri & - \\
\hline 18 & Paks & TA Kam & Suure-Kambja & - \\
\hline 19 & Paks & TA Ksi & Laeva & 5 \\
\hline 20 & Paks & TA Rõn & Suure-Rõngu & 15 \\
\hline 21 & Paks & VL Trv & Uue-Suislepa & 1 \\
\hline \multicolumn{4}{|c|}{ Neg kokku } & 68 \\
\hline 22 & Ilus & HA Hag & Kurtna & - \\
\hline 23 & Ilus & PÄ Hls & Õisu & 42 \\
\hline 24 & Ilus & TA Rõn & Hellenurme & 6 \\
\hline 25 & Ilus & VI Jõh & Illuka & 1 \\
\hline 26 & Ilus & VL Hel & Patküla & 4 \\
\hline 27 & Ilus & VÕ Krl & Karula & 1 \\
\hline 28 & Kuningas & PE & Pankjavitsa & - \\
\hline
\end{tabular}




\begin{tabular}{|c|c|c|c|c|c|c|c|}
\hline $\begin{array}{c}\text { Nimesaajate } \\
\text { staatus }\end{array}$ & 1870 & 1900 & 1935 & $2021^{*}$ & $\begin{array}{c}\text { Nimekandjaid } \\
\text { kokku kuni } 1935\end{array}$ & $\begin{array}{c}\text { Hääbumise } \\
\text { aasta }\end{array}$ & $\begin{array}{c}\text { Hääbumise } \\
\text { põhjus }\end{array}$ \\
\hline$S$ & - & - & - & - & 1 & 1853 & $\mathrm{D}$ \\
\hline SV & 5 & - & - & - & 14 & u 1900 & $\mathrm{D}$ \\
\hline- & - & 1 & - & - & 1 & 1907 & $\mathrm{D}$ \\
\hline$S$ & 4 & - & - & - & 16 & $\sim 1880$ & $\mathrm{O}$ \\
\hline PS & - & - & - & - & 21 & 1858 & $\mathrm{O}$ \\
\hline $\mathrm{S}$ & - & - & - & - & 1 & 1841 & $\mathrm{O}$ \\
\hline- & - & - & - & - & 28 & 1867 & $\mathrm{O}$ \\
\hline PS & 9 & 4 & 1 & - & 25 & 1954 & DO \\
\hline $\mathrm{S}$ & - & - & - & - & 1 & 1836 & $\mathrm{D}$ \\
\hline $\mathrm{V}$ & 10 & 17 & 1 & - & 55 & 1941 & $\mathrm{O}$ \\
\hline $\mathrm{P}$ & 31 & 52 & 72 & u 24 & 185 & - & \\
\hline $\mathrm{S}$ & - & - & - & - & 1 & $>1834$ & $\mathrm{D}$ \\
\hline SV & 5 & - & - & - & 12 & $\sim 1890$ & $\mathrm{O}$ \\
\hline $\mathrm{V}$ & 1 & - & - & - & 4 & 1871 & $\mathrm{D}$ \\
\hline$S$ & 8 & 6 & 3 & - & 21 & 1950 & $\mathrm{D}$ \\
\hline$S$ & 7 & 13 & 11 & - & 34 & 1986 & $\mathrm{D}$ \\
\hline- & - & - & - & - & 3 & $?$ & $?$ \\
\hline- & - & - & - & - & 2 & $<1888$ & $?$ \\
\hline $\mathrm{V}$ & - & - & - & - & 7 & 1859 & $\mathrm{O}$ \\
\hline PS & 24 & 35 & 27 & u 49 & 127 & - & \\
\hline \multirow[t]{2}{*}{$\mathrm{S}$} & - & - & - & - & 1 & $<1851$ & $\mathrm{D}$ \\
\hline & 104 & 128 & 115 & 73 & 560 & & \\
\hline- & - & 2 & - & - & 3 & $>1917$ & $\mathrm{D}$ \\
\hline PS & 94 & 119 & 113 & u 170 & 397 & - & \\
\hline $\mathrm{P}$ & 2 & 5 & - & - & 22 & 1917 & $\mathrm{D}$ \\
\hline$S$ & - & - & - & - & 2 & $>1857$ & $\mathrm{D}$ \\
\hline $\mathrm{S}$ & 7 & 11 & 8 & u 3 & 37 & - & \\
\hline $\mathrm{S}$ & - & - & - & - & 6 & $>1857$ & $\mathrm{D}$ \\
\hline- & - & - & 1 & $?$ & 3 & $?$ & $?$ \\
\hline
\end{tabular}




\begin{tabular}{|c|c|c|c|c|}
\hline $\mathrm{Nr}$ & Nimi & $\begin{array}{l}\text { Maakond, } \\
\text { kihelkond }\end{array}$ & $\begin{array}{l}\text { Mõis } \\
\text { (vald) }\end{array}$ & $\begin{array}{c}1826 / 1835 \\
\text { nimesaajaid }\end{array}$ \\
\hline 29 & Kuningas & PE & Petseri & - \\
\hline 30 & Kuningas & PÄ Saa & Jäärja & 42 \\
\hline 31 & Kuningas & VI Jõh & Ohakvere & 11 \\
\hline 32 & Kuningas & VL Trv & Tarvastu & - \\
\hline 33 & Kuningas & VÕ Rõu & Saaluse & 6 \\
\hline 34 & Kuningas & VÕ Rõu & Vana-Roosa & 15 \\
\hline 35 & Kuningas & VÕ Räp & Kahkva & 4 \\
\hline 36 & Tarkus & SA Kär & Kärla & 15 \\
\hline 37 & Tarkus & TA & Tartu & - \\
\hline 38 & Tarkus & VI Hlj & Vihula & 10 \\
\hline 39 & Tarkus & VI Jõhvi & Illuka & 7 \\
\hline 40 & Tarkus & VÕ Kan & Erastvere & 6 \\
\hline 41 & Truumees & HA Jür & Rae, Kautjala & 6 \\
\hline 42 & Truumees & JÄ Ann & Purdi & 7 \\
\hline 43 & Truumees & SA Kaarma & Kaarma-Suuremõisa & 16 \\
\hline 44 & Truumees & SA Khk & Karala & 19 \\
\hline 45 & Truumees & SA Pöi & Kingli & 4 \\
\hline 46 & Truumees & SA Pöi & Koigi & 16 \\
\hline \multicolumn{4}{|c|}{ Pos kokku } & 238 \\
\hline \multicolumn{4}{|c|}{ Kokku } & 306 \\
\hline
\end{tabular}

* 2021. aasta andmed on ligikaudsed, kuna isikute tasandil pole uuritud, mis sugukonda keegi kuulub (nt nime Ilus võeti ka eestistamisel ning neid sugukondi ei uuritud). Osa nimede puhul on tõenäoline ka võõrpäritolu (eelkõige perekonnanimi Kuningas Soomest). 


\begin{tabular}{|l|c|c|c|c|c|c|c|}
\hline $\begin{array}{c}\text { Nimesaajate } \\
\text { staatus }\end{array}$ & $\mathbf{1 8 7 0}$ & $\mathbf{1 9 0 0}$ & $\mathbf{1 9 3 5}$ & $\mathbf{2 0 2 1}$ & $\begin{array}{c}\text { Nimekandjaid } \\
\text { kokku kuni 1935 }\end{array}$ & $\begin{array}{c}\text { Hääbumise } \\
\text { aasta }\end{array}$ & $\begin{array}{c}\text { Hääbumise } \\
\text { põhjus }\end{array}$ \\
\hline- & - & - & 8 & u 10 & $\mathbf{1 2}$ & - & \\
\hline PHSK & 96 & 189 & 200 & u 370 & $\mathbf{6 1 6}$ & - & \\
\hline P & 17 & 27 & 40 & u 20 & $\mathbf{9 9}$ & - & \\
\hline- & - & 4 & - & - & $\mathbf{4}$ & 1933 & D \\
\hline S & 9 & 12 & 11 & $<10$ & $\mathbf{4 2}$ & - & \\
\hline P & - & - & - & - & $\mathbf{2 5}$ & 1840 & O \\
\hline P & - & - & - & - & $\mathbf{4}$ & $<1859$ & D \\
\hline P & 20 & 22 & 39 & u 20 & $\mathbf{1 0 1}$ & - & \\
\hline- & - & 2 & - & - & $\mathbf{4}$ & 1924 & D \\
\hline P & 30 & 32 & 25 & u 15 & $\mathbf{9 7}$ & - & \\
\hline P & - & - & - & - & $\mathbf{7}$ & 1835 & O \\
\hline P & 18 & 28 & 34 & u 40 & $\mathbf{8 6}$ & - & \\
\hline PS & - & - & - & - & $\mathbf{8}$ & 1865 & D \\
\hline K & 4 & 8 & 8 & u 5 & $\mathbf{3 2}$ & - & \\
\hline P & 15 & 40 & 37 & $>10$ & $\mathbf{1 1 2}$ & - & \\
\hline PV & 9 & 4 & - & - & $\mathbf{3 8}$ & 1913 & D \\
\hline P & 5 & 12 & 14 & u 10 & $\mathbf{4 1}$ & - & \\
\hline P & 6 & 13 & 14 & $>10$ & $\mathbf{5 8}$ & - & \\
\hline & 332 & $\mathbf{5 3 0}$ & $\mathbf{5 5 2}$ & $\mathbf{7 4 2}$ & $\mathbf{1 8 5 6}$ & & \\
\hline & $\mathbf{4 3 6}$ & $\mathbf{6 5 8}$ & $\mathbf{6 6 7}$ & $\mathbf{8 1 5}$ & $\mathbf{2 4 1 6}$ & & \\
\hline
\end{tabular}




\title{
Koer 'dog' or Kuningas 'king'? Persistence of Estonian surnames
}

\author{
FRED PUSS
}

Four Estonian surnames with negative and four with positive connotation were researched using the genealogical method (2,416 name bearers) to study their development, changes and persistence until 1935 on an individual level and on a general level for analysis. General bestowal of surnames took place in Estonia in 1822-1835. Then it was a process aimed from up to down - name givers were mostly German landlords and clergymen. Many names with negative connotation were also bestowed, for instance in the present research Koer 'dog', Laisk 'lazy', Limukas 'rainworm; snail', Paks 'fat'. Altogether 21 families had those names. Positive names (in this study Ilus 'pretty', Kuningas 'king', Tarkus 'wisdom', Truumees 'faithful man') appeared in 25 families. In some cases, the names also emerged after $1822-1835$ as parallel names or in 1921 in Petseri county.

Negative names were in $75 \%$ of the researched cases the bestowed to lower peasant classes (farmhands and cottagers) and to smaller families or single persons (average 4.3 initial name bearers). Positive names were usually bestowed to higher peasant classes (farmers, schoolteachers, $75 \%$ of the researched cases) and to larger groups of people (11.9 average initial name bearers). In only $10 \%$ of the researched cases the negative name still exists today, as opposed to $52 \%$ of the positive names.

The most important factors in surname extinction were as follows (in order of substance).

1. Small amount of initial name bearers $-100 \%$ of researched names with one initial bearer became extinct ( $88 \%$ within fifty years) regardless of the connotation.

2. Later demographical reasons - higher class families had more children until the demographic transition which in Estonia took place around the turn of the 19th-20th centuries. This enabled positive names (as these were being given to higher class families) to spread more as the first half century was important for a surname to start spreading. A negative name was not a reason for poor fertility performance, but the latter was caused by lower social status, which was more often connected with negative names.

3. Name changes $-33 \%$ of all negative names underwent extinction through name change, mostly before the end of the 19th century. A few positive 
names also experienced name change. Of the now-extinct names, $47 \%$ of negative and $75 \%$ of positive names became extinct for demographic reasons. Thus, name change was the reason for the extinction of $37 \%$ of negative names, while for positive names the only major cause of extinction was demographic.

4. Individual reasons. Some families had higher than average child mortality rates even in higher classes. In small families, many factors that did not affect bigger families could be fatal to surname spread, like a larger number of daughters or generations of men facing World War I and II (fathers and sons), also place of living (smaller infant and child mortality in state estates) and again social status (higher classes had more options to avoid the $80 \%$-fatal military service until 1874).

In the 1920s and 1930s a campaign of Estonianizing surnames took place. This also opened the possibility of changing ill-sounding names. No names from the present research became completely extinct during that campaign, but in one case 27 bearers of the name Laisk 'lazy' changed their name together in 1922 to Laaneväli 'forest plain'. Only one member of the family (the widowed mother of some name changers) did not change her name and died in 1941 as the last name bearer.

Keywords: Estonian surnames, family names, surname extinction, surname changes, Estonian anthroponomastics

Fred Puss

Eesti Keele Instituut

Ajaloo ja arheoloogia instituut

Tartu Ülikool

Jakobi 2-222

51005 Tartu

fred.puss@eesti.ee 